\title{
AMERICAN AND ENGLISH BALL CLAYS.
}

\author{
By H. H. Sortwell.
}

ABSTRACT.

The six American and fifteen English clays in use in the largest quantities were studied. No great differences were noted in water of plasticity, all of the clays falling within a range of a few per cent. The Dorset clays showed a slightly higher drying shrinkage than the other clays tested.

The transverse strength of the Tennessee clays when mixed with an equal weight of flint averaged 366 pounds per square inch, the Kentucky clays 282, the Dorset clays 405 , the Devon clays 443, and English clays, whose source was not known, 4I9. The American clays contained less mineral and carbonaceous matter which would be retained by 120 mesh. The rate of flow of slips through the efflux viscosimeter did not appear to be a valuable criterion in differentiating between ball clays.

The Kentucky clays were almost free from carbonaceous material requiring oxidation, the Tennessee and Dorset clays contained a small amount, while the Devon clays were highly carbonaceous and difficult to oxidize. The American clays showed a gradual reduction in porosity, and the volume was constantly changing from cone or to cone I2. Only one domestic clay was vitrified by cone 8. The English clays vitrified at a low temperature and remained almost constant in porosity and volume up to cone I2. No evidence of overfiring was observed. In a standard body the Tennessee clays as a class gave the best color, the Kentucky and Devon clays were next, and the Dorset clays were comparatively poor in coloring effect. From the results of the work a classification of ball clays has been drawn.

\section{CONTENTS.}

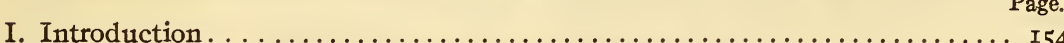

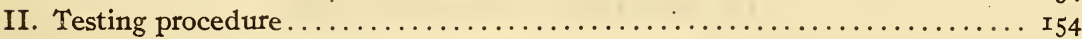

I. Water of plasticity.................................. I55

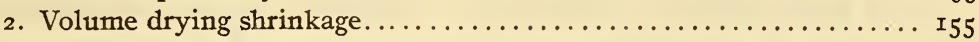

3. Transverse strength.............................. I55

4. Residue on I20-mesh sieve ......................... I55

5. Rate of flow of clay slips........................... I55

6. Cohesion of the plastic clay ......................... ${ }_{5} 6$

7. Oxidation of carbonaceous material ..................... ${ }_{5} 6$

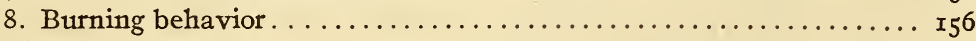

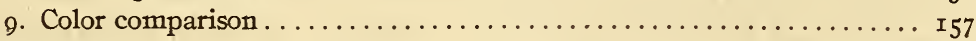

III. General results . . . . . . . . . . . . . . . . . . . . . . . . . . I $^{8}$

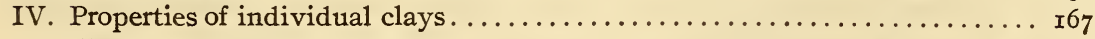

V. Classification of ball clays............................... I 73

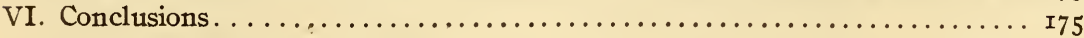




\section{INTRODUCTION.}

To fill a need long felt by the manufacturers of all ceramic products in which ball clays are used, the Bureau of Standards has conducted an investigation of the properties of all of these clays now in use which were available for testing. Although the general points of difference of the American and English clays were known, no systematic comparative data on the properties of any large number of the clays were available. Ball clay as a raw material of the ceramic industries is indispensable, being used in the manufacture of semiporcelain, china, sanitary ware, electrical porcelain, floor and wall tile, etc. It is used in every white ceramic body with very few exceptions.

The behavior of a body in casting, jiggering, pressing, or dry pressing depends, primarily, on the ball clay content. Ball clays, with their large drying shrinkage and high bonding power, largely control the ability of a body to successfully dry in large and complicated shapes and determine the strength of the ware in the green state. By their comparatively low temperature of vitrification they affect the maturing temperature and burning behavior of a body. The iron content of the ball clays largely influences the color of the finished product. Ball clays high in carbonaceous matter may cause defects in large pieces of ware when insufficient care is exercised in firing.

In view of the great importance of ball clays to the industry and of the difficulties which may be met in changing from one clay to another with no definite ideas of the comparative properties and the variations likely to be encountered, information concerning the clays employed is of interest and usefulness.

\section{TESTING PROCEDURE.}

The tests made on each clay consisted of the determination of the water of plasticity, volume drying shrinkage, the transverse strength of the clay mixed with an equal weight of flint, the residue retained on a I 20-mesh sieve, the rate of flow of slips of several water contents, the cohesion of the plastic clay with various water contents, the time required to oxidize the carbonaceous material, the burning behavior, and the coloring effect in a standard body. The methods employed were with some exceptions those generally used in work of this kind, and were in detail as follows: 
1. WATER OF PLASTICITY.

After crushing to pass a ro-mesh sieve the clay was tempered with water, thoroughly wedged by hand, and made into briquettes $2 \mathrm{I} / 2$ by $\mathrm{I}$ by $\mathrm{I}$ inches. Great care was taken to attain as nearly as possible the same degree of workability with each clay, After taking the wet weight the pieces were completely dried successively at room temperature, at 65 and $I I^{\circ} \mathrm{C}$., and the weights again taken. The water of plasticity was calculated in percentages of the weight of dry clay.

\section{VOLUME DRYING SHRINKAGE.}

The volume drying shrinkage corresponding to the water of plasticity was determined by means of the Schurecht picnometer using kerosene. The volumes of the wet pieces were determined after immersion in kerosene several hours, and after drying at room temperature, at 65 and $\mathrm{IIO}^{\circ} \mathrm{C}$., the pieces were allowed to soak in kerosene over night and the volumes again determined. The drying shrinkage was calculated in terms of the wet volume of the clay. From the data obtained the ratio of pore water to shrinkage water was calculated by means of the usual formulas. ${ }^{1}$

\section{TRANSVERSE STRENGTH.}

Each clay was mixed with an equal weight of commercial flint and molded into bars 6 by $\mathrm{I}$ by $\mathrm{I}$ inches. After drying at room temperature, at 65 and $\mathrm{IIO}^{\circ} \mathrm{C}$., the pieces were allowed to cool in a desiccator and broken transversely. Fifteen pieces of each clay were tested and the moduli of rupture calculated by the usual formula.

\section{RESIDUE OIN 120-MESH SIEVE.}

Ten grams of each clay were washed through a small I 20-mesh sieve $2 \frac{1}{2}$ inches in diameter. After drying at $110^{\circ} \mathrm{C}$. the residue was weighed and computed into percentage of the original clay.

\section{RATE OF FLOW OF CLAY SLIPS.}

Five slips of each clay between the limits of 5 and 40 per cent were made and the rates of flow of the slips through the simple efflux viscosimeter ${ }^{2}$ determined. To prepare the slips, the water and clay, with a few shot to accelerate disintegration, were put into bottles of 500 cc capacity and rotated for one hour in an agitator making 20 revolutions per minute. This was found

\footnotetext{
1 Report of the Committee on Standards, American Ceramic Society, p. 20, rgr \&

2 B. S. Tech. Papers, No. 5 I.
} 
to be sufficient to disintegrate these clays to the ultimate fineness they would attain without grinding. Several determinations were made on each slip. The results are given as the ratios of the rate of flow of distilled water at $20^{\circ} \mathrm{C}$. to the rates of flow of the slips and are termed "relative resistance to flow" in this work. The water content of the slips was determined by evaporating to dryness at $110^{\circ} \mathrm{C}$. a small quantity of each slip and weighing the residue.

\section{COHESION OF THE PLASTIC CLAY.}

The cohesion of the plastic clay was determined by means of the apparatus shown in Figure I. The receptacle $a$ was filled with the plastic clay and the glass disk $b$ slid into position in such a manner that the entire surface was in contact with the clay. Shot were then allowed to run into the cup $c$ until the weight was sufficient to pull the plastic clay apart. In every case the adhesion of the clay to the glass and metal was greater than the cohesion of the clay. Five determinations were made on each mixture. The results are given in grams per square centimeters required to pull apart the plastic clay.

\section{OXIDATION OF CARBONACEOUS MATERIAL.}

Briquettes 2 by $\mathrm{I} / 4$ by $\mathrm{I} / 4$ inches were molded from each clay and after drying were placed in a gas-fired semimuffle furnace. The temperature was raised to $750^{\circ} \mathrm{C}$. in five hours, and the furnace was held at that temperature. Trials of each clay were drawn at half-hour intervals and broken to observe the progress in the burning out of the carbonaceous matter. Oxidizing conditions were maintained throughout the test.

\section{BURNING BEHAVIOR.}

Standard size briquettes of the clays were molded, dried, and the dry volumes determined, after which they were placed in a gasfired muffle kiln, and the temperature was raised to $750^{\circ} \mathrm{C}$. in I 8 hours. The kiln was held at that temperature until trials of the most carbonaceous of the clays indicated that oxidation was complete. The muffle was then heated to cone 12 at a rate of $20^{\circ}$ C. per hour. Trials were drawn at cones or, 2, 4, 6, 8, го, and I 2 and were immediately transferred to an auxiliary chamber at red heat, where the entire set of specimens was allowed to cool slowly. The pieces were weighed dry, and after saturation with water by boiling under a vacuum for one hour were weighed suspended in water and under atmospheric conditions. The 
porosities were calculated by the Purdy formula. ${ }^{3}$ The volume shrinkages were calculated in percentages of the dry volumes before firing. In addition, the true specific gravities of the trial pieces fired at cones 8 and $\mathrm{I} 2$ were determined by the usual pycnometer method. From the resulting data the inclosed pore space and total true porosities based on the true clay volumes were calculated. ${ }^{4}$

\section{COLOR COMPARISON.}

For a better comparison of the coloring effect of the clays in a body than could be drawn from the burned trial pieces, a standard body composition was made containing each clay. The body used

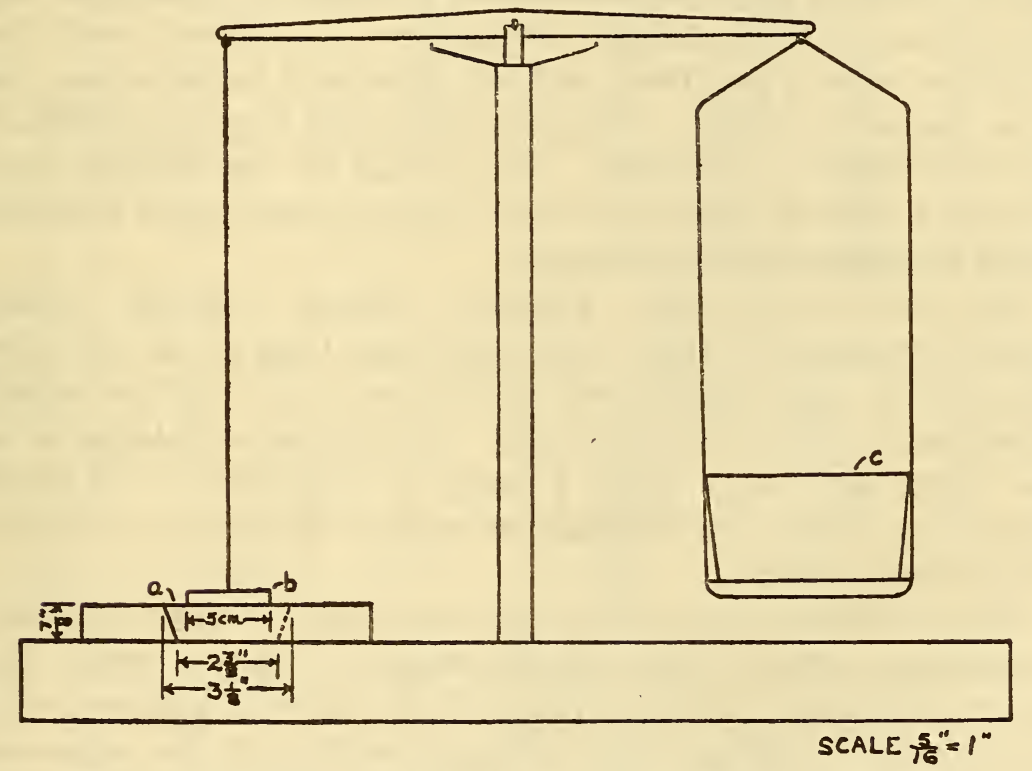

FIG. I.-Apparatus for determining the cohesive strength of plastic clay.

was 50 per cent ball clay, 30 per cent flint, and 20 per cent feldspar. Each body was ground in a small ball mill for four hours, passed through a I2O-mesh lawn, dried to plastic condition, and jiggered into disks $3 \frac{\pi}{2}$ inches in diameter by one-fourth inch thick. The disks were then fired to cone 9 in oxidizing conditions and compared in regard to color. The clays were grouped into three classes according to their coloring effect in the standard body. Class I consisted of the clays giving the best white color, class 2 the intermediate, and class 3 the clays giving comparatively poor color in the body.

3 Purdy, R. C., Bulletin No. 9, Illinois Geological Survey.

Bleininger and Montgomery, Trans. Am. Ceram. Soc., 15, p. 73, rgr3. 


\section{GENERAL RESULTS.}

Since there are several more brands of English ball clays on the American market than domestic clays, the number of English clays included in the present work is proportionately larger than the number of American clays studied. From the answers to a questionnaire sent to a large number of manufacturers of earthenware, china, electrical porcelain, sanitary ware, and wall and floor tile, the clays studied were chosen as those being used in the largest quantities at the time.

The results of the tests are given in Tables $I, 2,3,4,5,6,7$, and 8, showing the basic differences between the American and English clays, between clays coming from the different producing localities in both countries, and the differences in clays from the same general localities. No great differences were discernible in regard to water of plasticity. The values for the different clays covered a range of several per cent, but no classes could be drawn based on geographical occurrence.

The clays from Dorset, England, showed a greater volume drying shrinkage by from 3 to 6 per cent than all of the other clays except one English clay whose source was not known and which might also be a Dorset clay. The drying shrinkages of all the other clays were within a range of 4 per cent. All of the clays tested showed a tendency to warp in drying, but none developed any cracks.

The transverse strength of equal mixtures of the clays with commercial potter's flint was determined to give a better idea of the comparative bonding power of the clays in pottery bodies than would be indicated by the determination of the transverse strengths of the clays alone. The results showed the English clays to be stronger than the American clays in general, although two of the American clays showed a modulus of rupture as high as some of the English clays which were of moderate bonding strength. The average modulus of rupture of the Tennessee clays studied was 366 pounds per square inch, while the Kentucky clays averaged 282 pounds per square inch in these mixtures. One of the Kentucky clays had a fair value for transverse strength, but the other two Kentucky clays were the lowest in this respect of all the clays studied. Of the English clays those from Devonshire were the strongest in the dry state, having an average transverse strength of 443 pounds per square inch. The clays from Dorset had an average modulus of rupture of 405 pounds per square 
inch. The English clays whose exact source was not learned averaged 4I9 pounds per square inch.

The American clays were much cleaner than most of the English clays, as shown by the residues of arenaceous material and organic matter which would not pass a I20-mesh screen. The Kentucky clays were almost free from such material, while the Tennessee clays contained only a small amount. In other

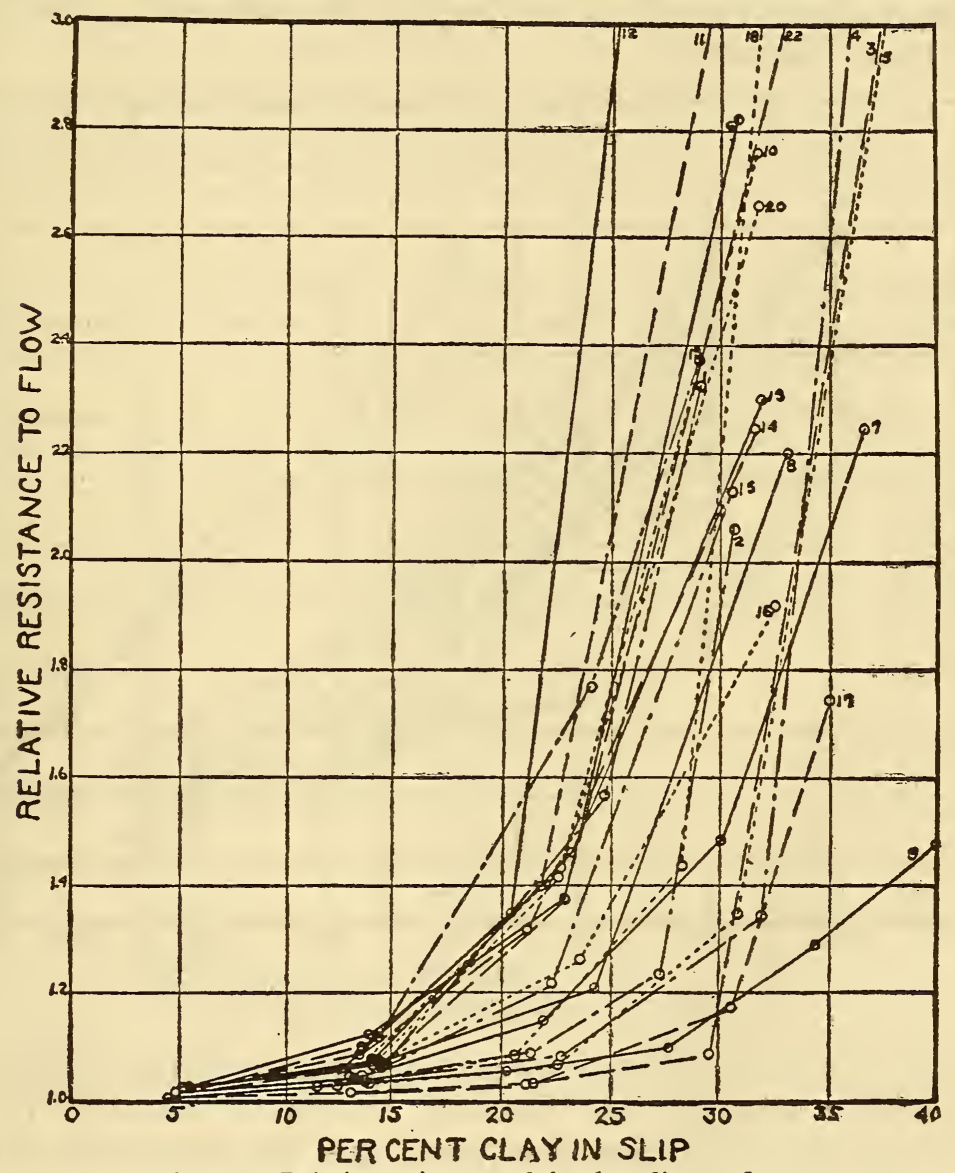

FIG. 2.-Relative resistance of the clay slips to flow.

words, the English clays contained more mineral matter and dirt, which have to be removed in the preparation of the body.

The efflux viscosimeter has seen much use in the study of slips for casting, and the rate of flow of clay slips through this apparatus has been considered a valuable criterion of the inherent plastic qualities of the clays. The results have always been referred to

$$
10008^{\circ}-23-2
$$


as "viscosity." Since Bingham ${ }^{5}$ has shown that slips of clay and water are examples of plastic flow rather than viscuous flow, the results in this work are referred to as "resistance to flow." The numerical results are given in Table 2. Soluble salts in the clays are apt to act as electrolytes and affect the results. Figure 2 shows graphically the results obtained and indicates that no geographical divisions can be made. The most plastic clay and the least plastic as well, as indicated by the behavior in slip form, were from Tennessee.

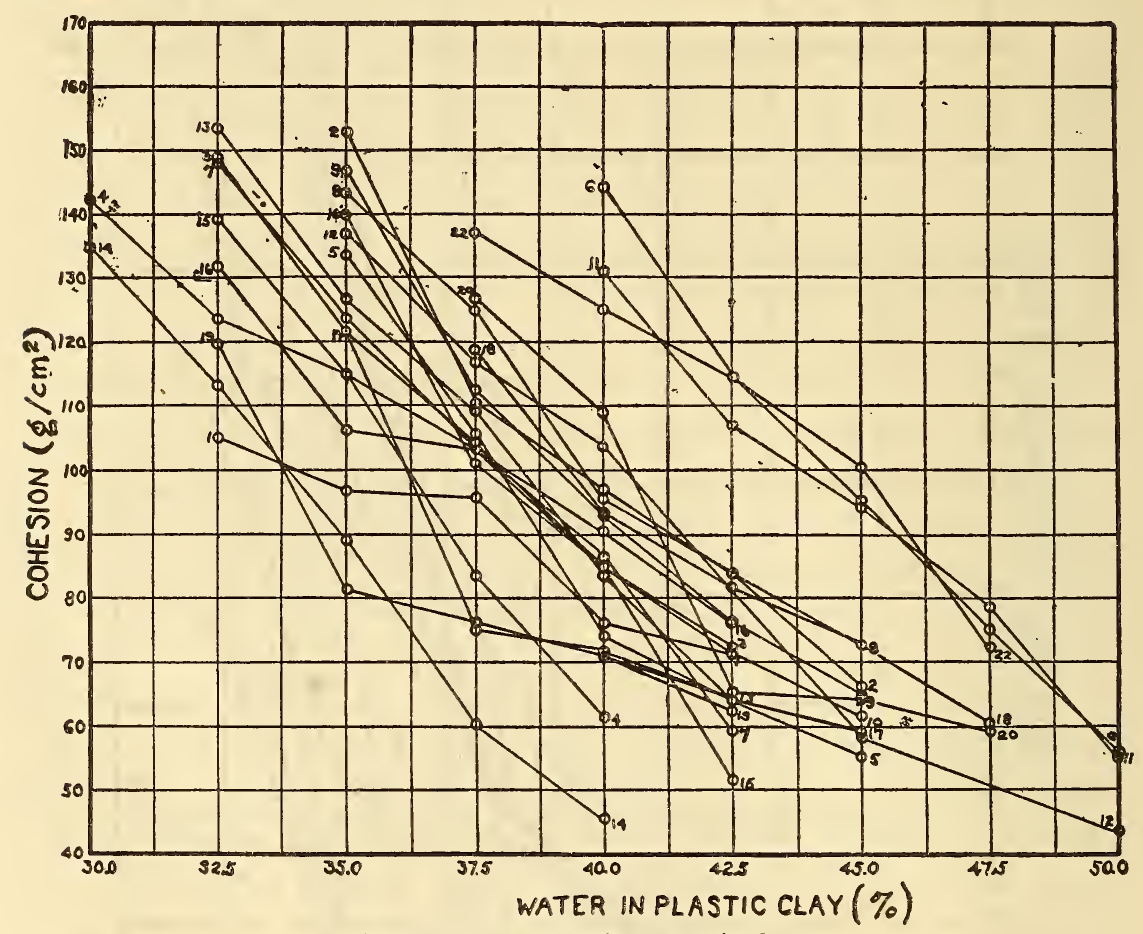

FIG. 3.-Cohesion of the plastic clays.

The "cohesion" of the plastic clays was determined to learn the comparative strength and bonding powers of the clays in the plastic condition. It was also hoped that the results would give a criterion of the behavior of the clays in jiggering, as those clays with the higher value for cohesion at a given water content work better by following the tool with less tendency to break. The results are shown in Table 3 and Figure 3 . Comparison of the results of the tests on the slips with those obtained for the cohesion of the plastic clays indicates that there is no direct connection between these two properties. While each probably measures one of the several components of plasticity, it is evident that neither

${ }^{6}$ Bingham, Eugene C., B. S. Sci. Papers, No. 278 , An Investigation of the Laws of Plastic Flow, p. 330. 
gives a differentiation of the clays in the order in which they are considered to have the best plastic working qualities.

The time required to burn out the carbonaceous matter in the clays showed several of the English clays to be very difficult to oxidize. Although carbonaceous matter of the type contained in these clays appears to indicate the plastic working qualities and bonding power in the green state, it may be a cause of trouble in some cases. In the manufacture of heavy pieces of sanitary ware, which are higher in ball clay than other white burning bodies, losses are apt to occur when these highly carbonaceous clays are used and insufficient time is allowed for oxidation in firing.

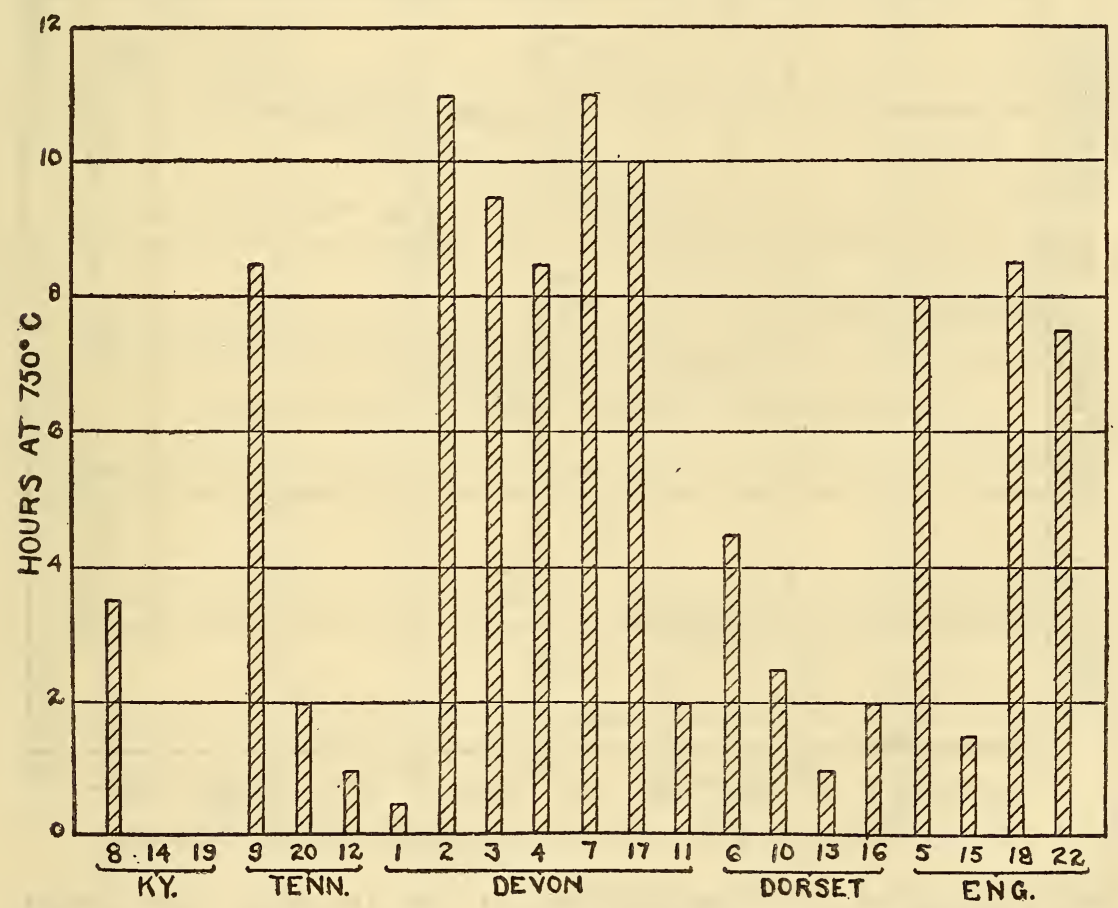

FIG. 4.-Hours oxidation at $750^{\circ} \mathrm{C}$. required to free the clays from carbonaceous matter.

Table 4 and Figure 4 show numerically and graphically the time required to oxidize the clays. With one exception the American clays were low in carbonaceous matter. Two of the Kentucky clays tested contained no material requiring oxidation. Tennessee ball clay No. 5 was high in carbon, but the other clays from Tennessee contained but little. The clays from Devonshire with one exception required the longest time for oxidation. The Dorset clays were not as carbonaceous as the clays from Devonshire, and, considered by groups, were about the same in oxidation requirements as the Tennessee clays. 
It is interesting to note the relation between the carbonaceous matter in the clays and the transverse strength. The two clays which contained no carbonaceous matter had the lowest transverse strength of the clays tested. The Devonshire clays as a class were the most carbonaceous and at the same time were the strongest in the green state. In the clays studied the amount of carbonaceous material and the transverse strength appear to be related, and it is safe to say that, although there is no proportionate relationship between these factors, the carbonaceous matter is associated with the strength of the clay. Figure 5 shows the transverse strength

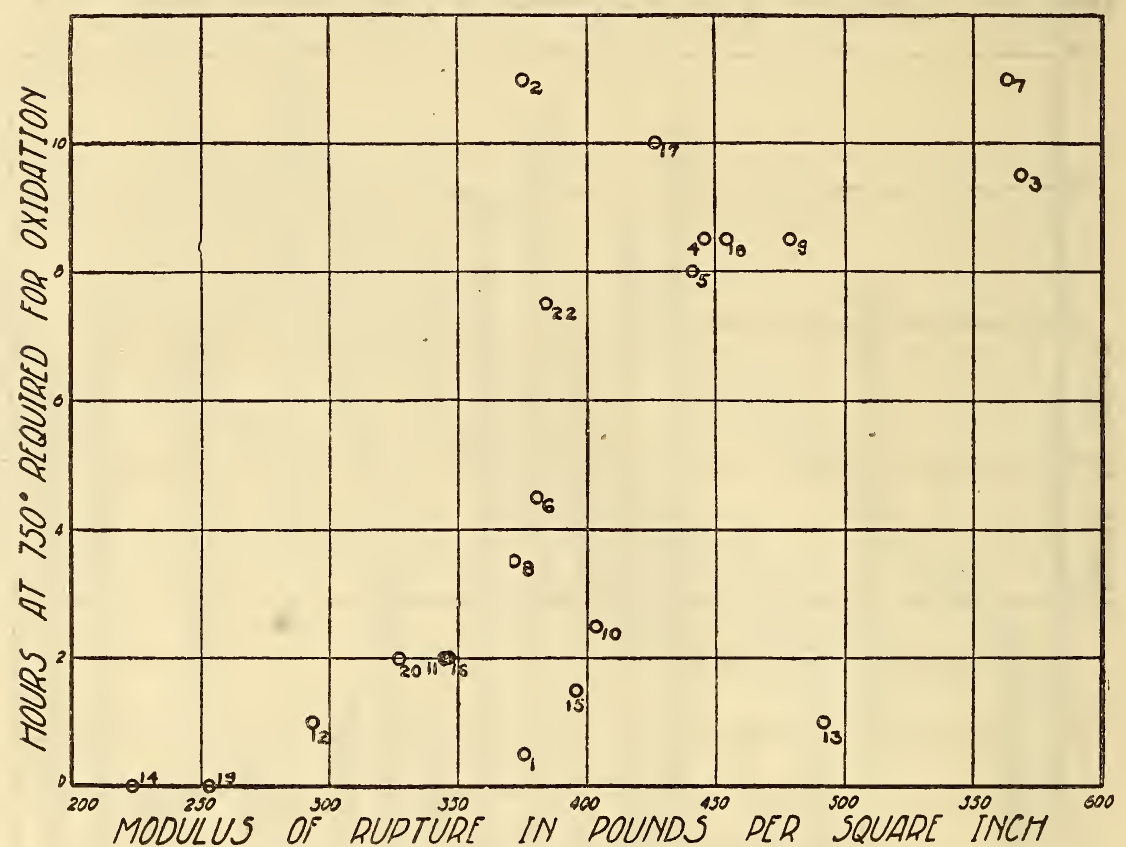

FIG. 5.-Comparison of transverse strength with time required for oxidation.

plotted against the time required to free the clays from carbonaceous matter.

The burning behaviors of the American and English clays shown in Tables 5 and 6 and in Figures 6, 7, 8, 9, ro, and I I were radically different. The English clays vitrified at a low temperature and remained almost constant in volume up to cone 12 , the maximum firing temperature used in this work. No evidence of overburning was noticed at cone 12 . There was some variation in the burning behavior of the clays from Devonshire, but the four Dorset clays tested all underwent practically the same changes in apparent porosity and volume during firing. The American clays showed a 
gradual reduction in porosity from cone or to cone 12 . Tennessee ball clay No. 5 was the only domestic clay studied which was matured at cone 8. Tennessee No. 3 matured at cone ro and

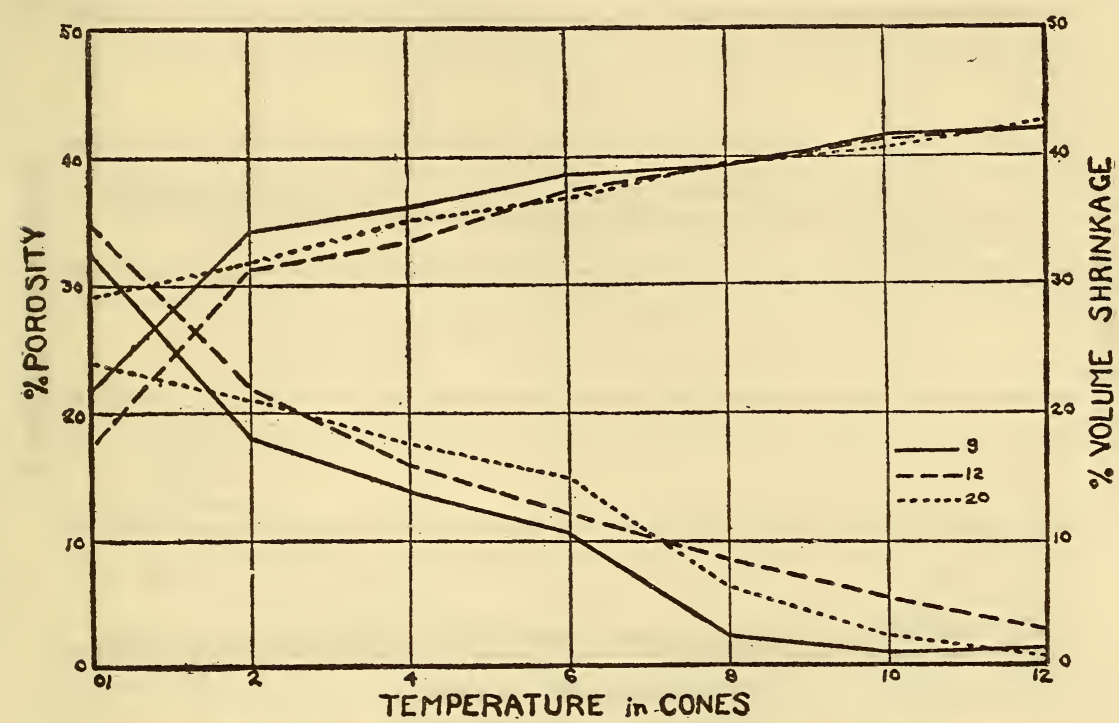

FIG. 6.-Porosity and volume changes in Tennessee ball clays.

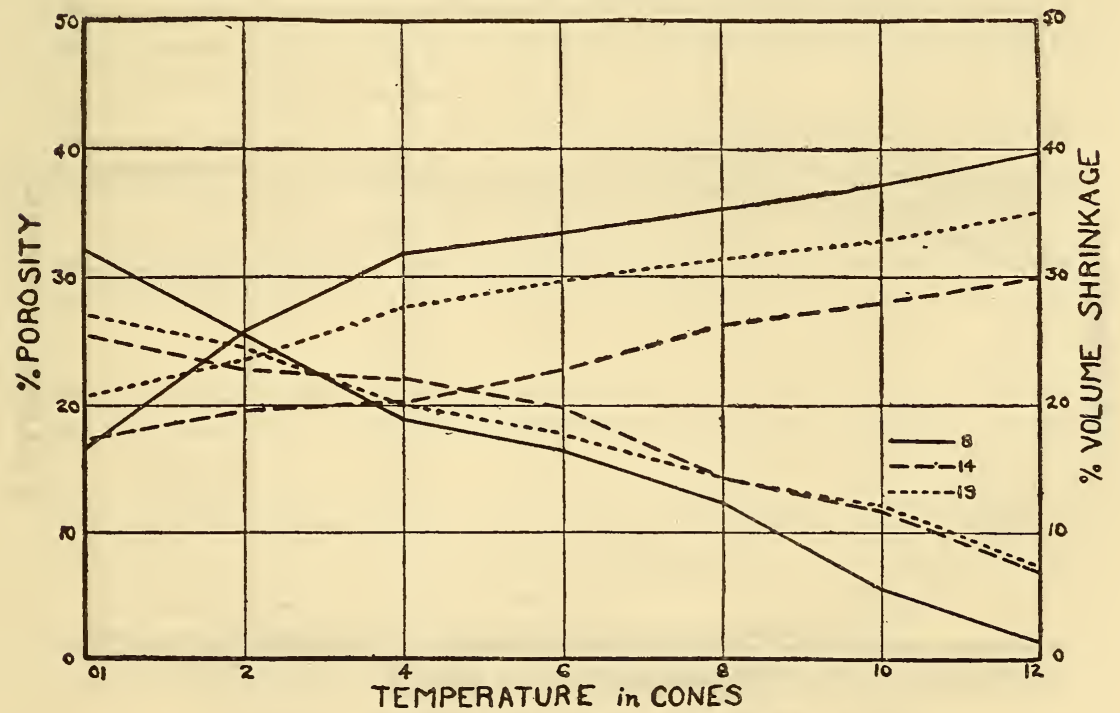

Fig. 7.-Porosity and volume changes in Kentucky ball clays.

Tennessee No. I I and Kentucky No. 4 at cone I2. The other two Kentucky clays were not yet vitrified at cone I2. Throughout the firing range studied the American clays were constantly de- 
creasing in volume. Figure 6 shows the burning behavior of the Tennessee clays, and Figure 7 shows that of the Kentucky clays. In general, the English clays have a more desirable burning be-

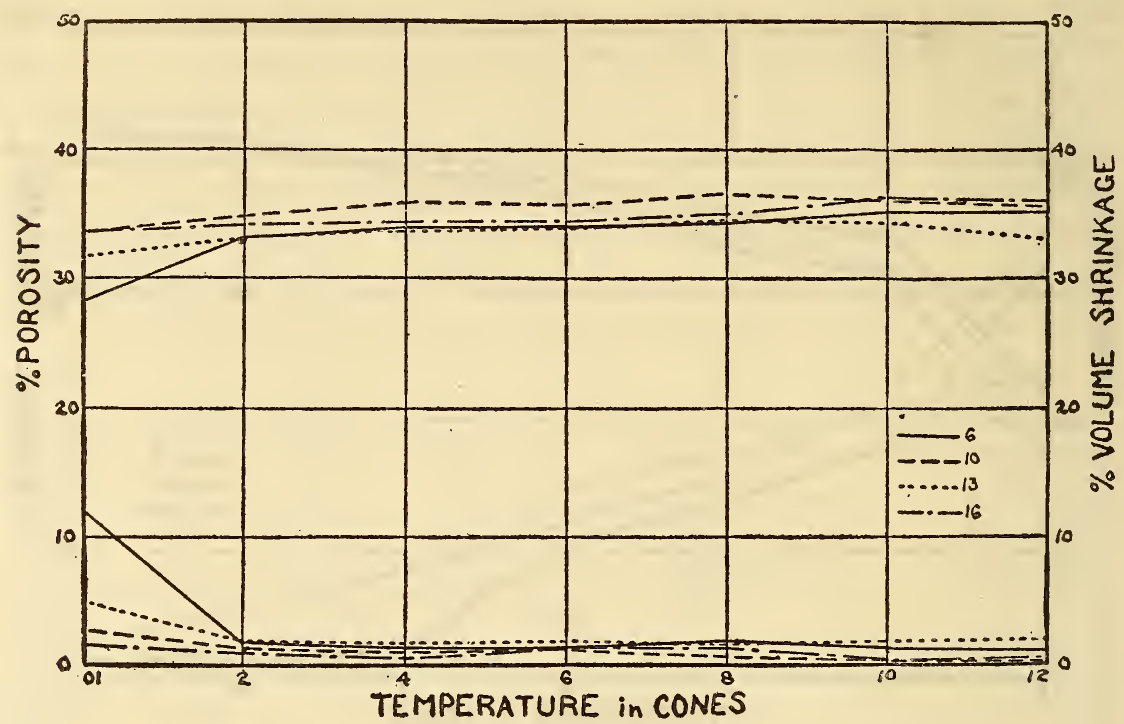

FIG. 8.-Porosity and volume changes in Dorset ball clays.

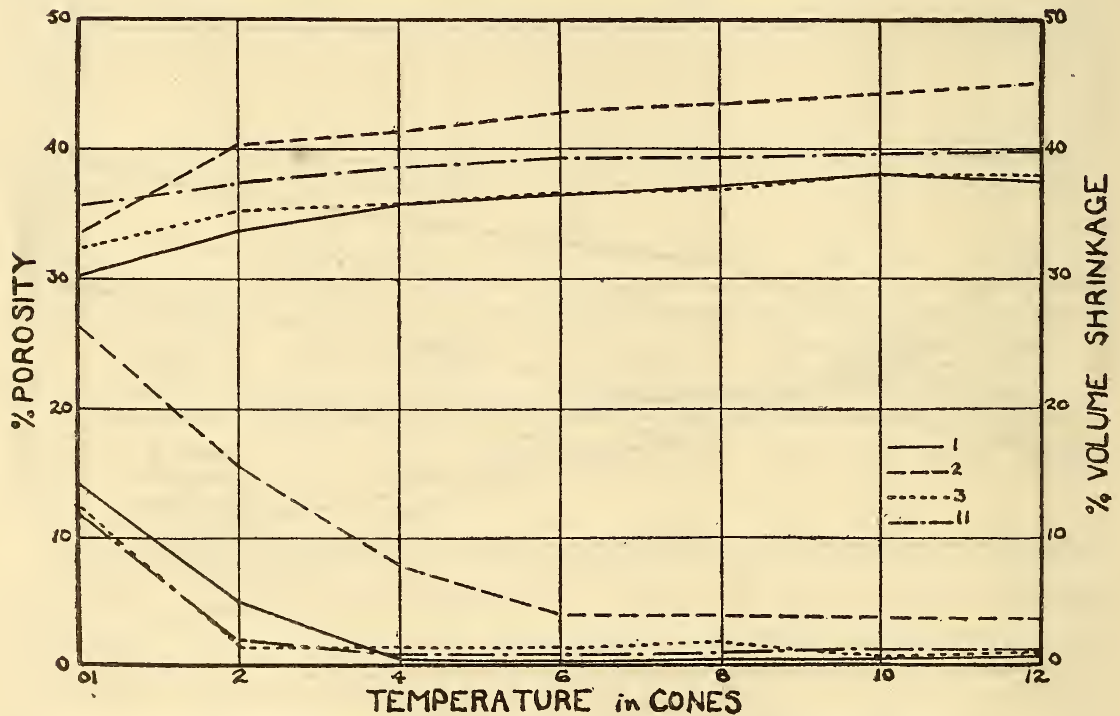

FIG. 9.-Porosity and volume changes in Devon ball clays.

havior than the American clays. The ball clay in a body should vitrify and give the ware strength additional to that derived from the fluxes. While all of the English clays vitrify before cone 8 , 
only one of the American clays does. Furthermore, the English clays remain almost constant in volume through a wide range in temperature, while the American clays change in volume with any change in heat treatment.

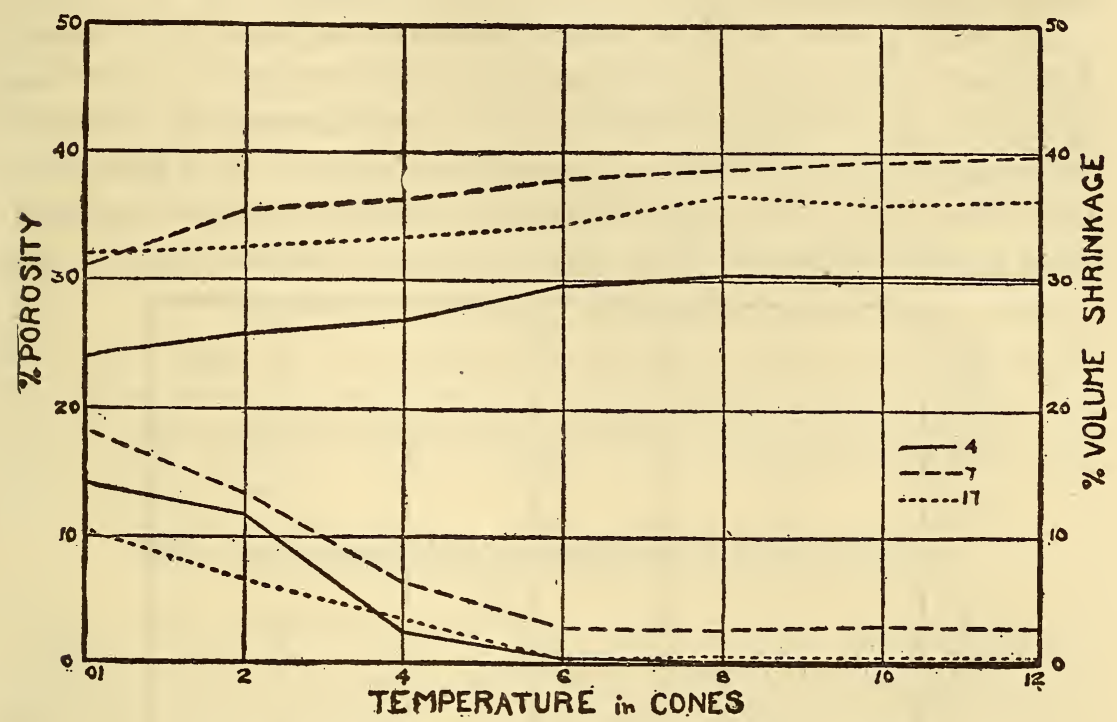

FIG. I0.-Porosity and volume changes in Devon ball clays.

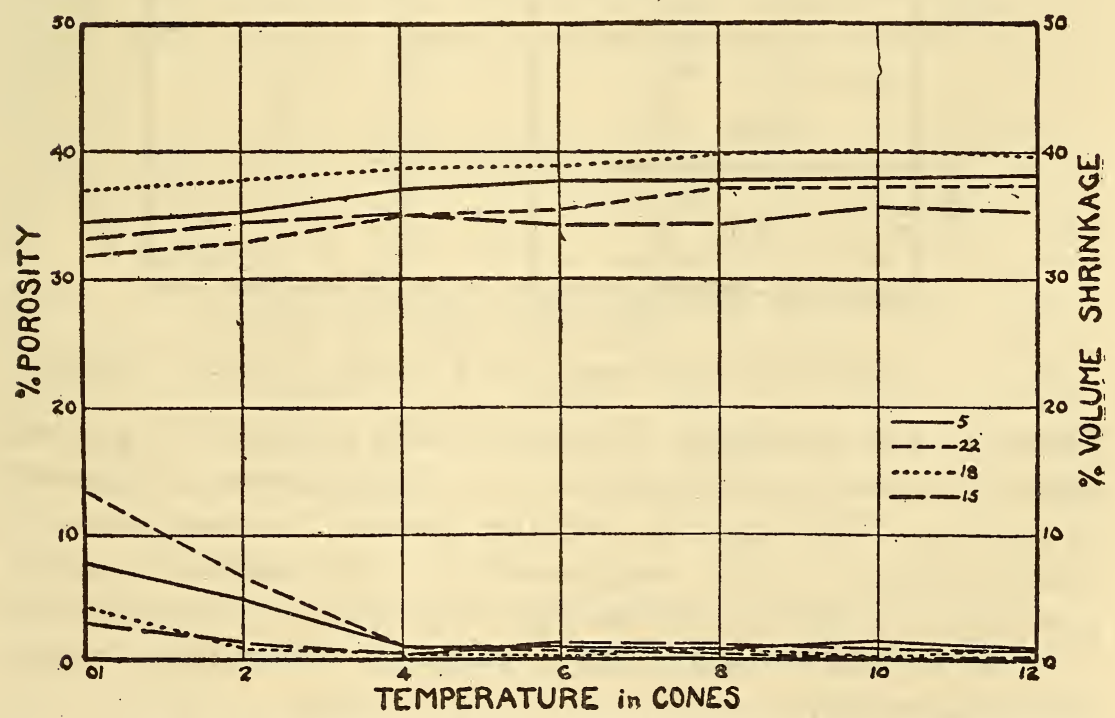

FIG. II.-Porosity and volume changes in English ball clays (exact source unknown).

Table 7 shows the true specific gravities, inclosed pore space, and total porosity in terms of the true clay volume of the clays fired at cones 8 and I2. In every case except three the true spe- 
cific gravity showed a slight reduction from cone 8 to cone I2, the degree depending on the clay. In the three exceptions a slight increase appeared, and in nearly every case there was a slight reduction in inclosed pores.

The results show an interesting connection between the amount of inclosed pore space and the amount of carbonaceous material. All of the clays which contained only a small amount of carbonaceous matter had inclosed pore space of from 4.5 to 9 per cent. All of the clays which were difficult to oxidize contained inclosed pores to the extent of from 10.5 to 22 per cent at cone 8 . In

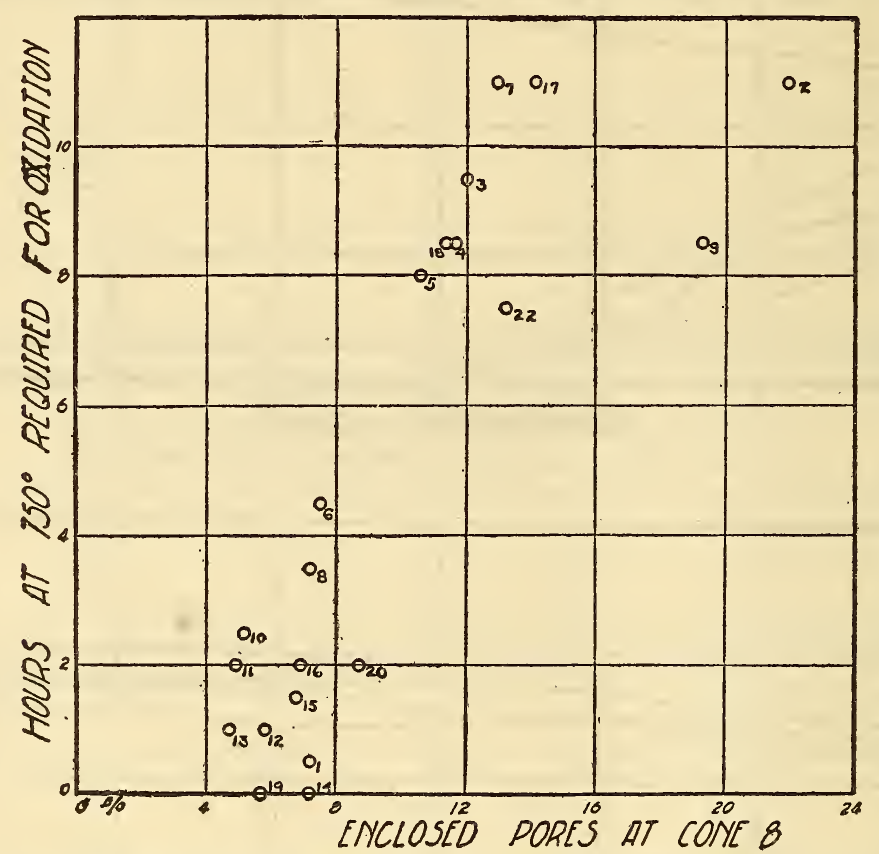

FIG. I2.-Comparison of inclosed pores at cone 8 with time required for oxidation.

Figure 12 the percentage of inclosed pores at cone 8 is plotted against the time required to burn out the carbonaceous material in the clay. That there is a relation between the two factors is clearly shown. In the manufacture of high tension electrical porcelain in which the inclosed pore space affects the dielectric strength it would be desirable to avoid the use of these highly carbonaceous clays.

In regard to color, two clays-Tennessee ball clay No. II and Knowles English ball clay No. 2-made excellent white bodies when used to the extent of 50 per cent of the body. Four other clays-two American and two English-were white enough to 
be included in class I. Eight clays-two domestic and six imported-were put in the intermediate class 2, and the five English clays and the one American clay which were poor in color in class 3. The classification by laboratory numbers was: Class I, Nos. 2, 3, 9, I 2, I8, and I9; class 2, Nos. I, 5, 6, 7, 8, II , 20, and 22; and class 3 , Nos. 4, I0, I3, I4, I5, 16, and I7. The American clays showed a very good color when fired, three being white enough to be included in class $\mathrm{I}$, two in class 2 , and only one in class 3. The majority of the Devonshire clays were in the second class, while three of the four Dorset clays were in the third class. The Tennessee clays had somewhat better color when fired than those of Kentucky. In general, it may be stated that the American clays are equal to and in many cases superior to most of the English clays in regard to the color produced in the body by their use.

\section{PROPERTIES OF INDIVIDUAL CLAYS.}

No. I. Knowles English Ball Clay No. i, North Devon DISTRICT.-This was a soft, sticky clay which worked up easily with very good plasticity. In its natural state it was clean gray in color and contained but little dirt and carbonaceous matter. It left only a small residue- 0.2 per cent-on the I 20 -mesh sieve. Its transverse strength was good, the modulus of rupture being 376 pounds per square inch. From its behavior in slip form in the viscosimeter it appeared to be of very good plasticity. In the plastic condition the strength of this clay, as indicated by the cohesion test, was a little below the average. The small amount of carbonaceous matter had disappeared after one-half hour at $750^{\circ} \mathrm{C}$. Its burning behavior, shown in Figure 9, was typical of the English clays. In color it was a clean, very light buff, which darkened a little as the temperature of firing was increased. It was placed in the second class in regard to color.

No. 2. Knowles English Ball Clay No. 2, Devonshire.This clay was of excellent plasticity and was sticky and required much wedging to free it from small lumps. It was black in color, indicating much carbonaceous matter, and contained a large amount of material, I.5 per cent, which would not wash through a r2o-mesh sieve. The modulus of rupture of the mixture of equal parts of clay and flint was 375 pounds per square inch. The behavior of the clay in the viscosimeter indicated it 
to be of good plasticity, and its strength in the plastic condition was good. This clay was very carbonaceous, the small trial pieces used requiring i I hours at $750^{\circ} \mathrm{C}$. to oxidize completely. Figure 9 shows its burning behavior. It vitrified at about cone 6, a higher temperature for vitrification than the average English clay. The body containing 50 per cent of this clay was an excellent white in color. In this respect it was one of the best two clays tested.

No. 3. Knowles English Ball Clay No. i2, Devonshire.This clay, brownish gray in color, was of excellent plasticity and working behavior. The residue left on the I2O-mesh sieve was 0.7 per cent. It was the strongest clay tested in the green state, having a modulus of rupture of 568 pounds per square inch when mixed with an equal weight of flint. Its great bonding power would make it especially desirable for use in large, heavy products, such as sanitary ware. The clay contained a great deal of carbonaceous matter, requiring nine and one-half hours at $750^{\circ}$ C. for complete oxidation. Its strength in plastic condition was about the average of that of the clays tested. It vitrified a little before cone 2 and showed no change from that point throughout the firing range studied. The tendency to warp in burning was very slight. The color of the body in which this clay was used was a fair white, and the clay was included in class I of the color classification.

No. 4. Hammill and Gillespie's "Whiteway" English Ball Clay, South Devon District.-In all its properties this clay very much resembled No. 3. Its strength in the clay-flint mixture was somewhat lower, the modulus of rupture being 446 pounds per square inch. To remove the carbonaceous matter, the $\mathrm{I} 1 / 4$-inch pieces were held at $70^{\circ} \mathrm{C}$. for eight and one-half hours. The burning behavior was similar to that of the other Devonshire clays, although its volume burning shrinkage was not as great. The color of the burned clay was poor, and it was included in the third class in regard to color.

No. 5. Paper Makers Chemical Co.'s English Ball Clay No. 90.- The exact source of this clay was not known. It was of excellent plasticity and somewhat "greasy." The amount of material retained by the $120-$ mesh sieve was 0.7 per cent. The bonding power was good, as shown by the modulus of rupture of 44I pounds per square inch. Its plasticity as indicated by the rate of flow of slips was a little below the average, as was its cohesion. It was fairly high in carbonaceous matter, the oxidation 
period required at $75^{\circ} \mathrm{C}$. being eight hours. Its burning behavior was typical of the English clays, and its color when burned was fair.

No. 6. Joshua Poole's "Pikes" Ball Clay, Dorset, EngLAND.-Like the other Dorset clays tested, the drying shrinkage of this clay was higher than the average. Its plasticity and working qualities were excellent. It was a clean gray of yellow cast in appearance and only 0.2 per cent was retained on the I 20 -mesh sieve. Its modulus of rupture when mixed with an equal weight of flint was $38 \mathrm{r}$ pounds per square inch. The strength of this clay in the plastic condition was the greatest of the clays tested, as shown by the cohesion determination. The behavior of slips of the clay indicated it to be of excellent plasticity. The briquettes were free from carbonaceous matter after being held four and one-half hours at $750^{\circ} \mathrm{C}$. It vitrified at cone 2 and remained constant in volume throughout the range in temperature studied. The color of the body containing this clay was fair.

No. 7. Moore and Munger's "Superior" Ball Clay, South DeVON District, England.-In appearance and in many of its properties this clay very much resembled No. 2. The black color would indicate a great deal of carbonaceous matter with the usual accompanying high bonding power. The I2O-mesh sieve retained 1.2 per cent of this clay. The modulus of rupture of the clay-flint mixture was very high, 563 pounds per square inch, making this clay, like No. 3, desirable for bodies where great strength is required. Being very carbonaceous it was necessary to hold this clay at $750^{\circ} \mathrm{C}$. for I I hours to completely remove the black core. Its burning behavior was similar to that of No. 2 . It was included in the second class in regard to color.

No. 8. Kentucky Construction and Improvement Co.'s Kentucky Ball Clay No. 4.-This clay was a clean light brown color and contained only o.I per cent of material which was retained by the $\mathrm{I} 2 \mathrm{O}$-mesh sieve. It was of very good plasticity and worked up easily. Its strength in the clay-flint mixture was good, as shown by the modulus of rupture of 372 pounds per square inch. Its cohesion was a little above the average. It contained but a small amount of carbonaceous matter which easily burned out in three and one-half hours at $750^{\circ} \mathrm{C}$. Its porosity gradually decreased from 32 per cent at cone or to I.4 per cent at cone 12 , and the volume decreased with each incre- 
ment in heat treatment. On the basis of the color of the standard body it was placed in class 2 .

No. 9. Mandle Clay Mining Co.'s, Tennessee Ball Clay No. 5. -The color of this clay was a pinkish brown. Its plasticity and working qualities were good and the modulus of rupture high478 pounds per square inch-indicating it to be the highest in bonding power of the domestic clays tested. Slips of this clay showed the highest rate of flow through the efflux viscosimeter and had the appearance of being deflocculated, probably due to a small amount of salts present. It also contained more carbon than the other American clays and required a period of eight and onehalf hours at $750^{\circ} \mathrm{C}$. for complete oxidation. The burning behavior is shown in Figure 6. It was vitrified by cone 8 . The standard body containing it burned to a good shade of white, entitling it to inclusion in the first color class.

No. io. C. M. Franzheim's Blue Ball Clay No. 25, Dorsett, ENGLAND.-This clay was a clean gray in color and of excellent plasticity, working up easily. The amount of material retained on the I2O-mesh sieve was fairly high, 0.9 per cent. Its strength in a body was high, as shown by a modulus of rupture when mixed with flint of 4.03 pounds per square inch. Its cohesion and the resistance to flow of the slips were about the average for the clays studied. It contained but little carbon and oxidized easily in two and one-half hours at $750^{\circ} \mathrm{C}$. This clay was vitrified at cone or, and remained almost constant in volume to cone $\mathrm{I} 2$. It was included in class 3 in the color comparison.

No. i i. C. M. Franzheim's "Devon" Bali Clay, Devonshire, ENGLAND.-This clay was gray in color, of very good plasticity, and tempered easily. The I 20 -mesh sieve retained 0.4 per cent. The modulus of rupture was 345 pounds per square inch, and the period at $750^{\circ} \mathrm{C}$. required to oxidize the carbonaceous matter was only two hours. This was one of the strongest clays tested in the plastic condition, as shown by the cohesion, and the resistance to flow of slips containing it would indicate it to be of excellent inherent plastic qualities. Its burning behavior closely resembled that of No. Io. In regard to comparative color it was placed in class 2.

No. i2. Johnson-Porter Co.'s Tennessee Ball Clay No. II.-As this clay is shipped it is a clean light pink in color, appearing to be free from carbonaceous matter. It was very plastic and worked up easily. Its cleanliness was indicated by the fact that all but 0. I per cent passed the I 20 -mesh sieve. Its strength when 
dried was somewhat low, as shown by the modulus of rupture of the flint-clay mixture, which was 293 pounds per square inch. The resistance to flow of slips of this clay would appear to indicate that it had the best plastic qualities of the clays tested. Its strength in the plastic condition was good. The amount of carbonaceous matter to be removed in burning this clay was very small, the $\mathrm{r} / 4^{-}$ inch briquettes being free from carbon one hour after $750^{\circ} \mathrm{C}$. was reached. Its behavior in burning shown in Figure 6 was typical of the Tennessee clays. The body containing 50 per cent of this clay burned to a fine white, and it was one of the two clays tested that were very much superior to all the others in regard to color.

No. I3. John Sant and Sons' "Dorset" Ball Clay, Dorset, ENGLAND.- In most of the properties studied this clay showed little difference from the other Dorset clays. It was very clean, only o.I per cent being retained by the I 20-mesh sieve. Its bonding power was excellent. It had the greatest transverse strength of the Dorset clays tested, having a modulus of rupture of 492 pounds per square inch when mixed with an equal weight of flint. The small amount of carbon present disappeared after the test pieces had been held at $750^{\circ} \mathrm{C}$. for one hour. Figure 8 shows that its burning behavior was typical of the Dorset clays.

No. i4. Cooley Ball and Sagger Clay Co.'s Kentucky Ball Clay No. IO.-This clay was very clean and almost white in the raw state. Its plasticity was good and it slaked easily. It contained practically no dirt nor coarse mineral matter, as only 0.04 per cent would not wash through a I20-mesh sieve. Its modulus of rupture of 223 pounds per square inch would indicate it to be somewhat deficient in strength in the dried state. Its behavior in slip form and when plastic is shown in Figures 2 and 3 . As indicated by its white color, it contained no carbonaceous matter and would require no oxidation in its burning. Its porosity and volume shrinkage relations are shown in Figure 7 . It was not vitrified at cone $\mathrm{I} 2$. Its volume shrinkage throughout the firing range studied was low. It was placed in class 3 of the color classification.

No. i5. Moore and Munger's English Ball Clay No. in, ENGLAND.-This English clay, the exact source of which was not learned, showed no distinct differences from the English clays in general studied. Its properties are shown in the tables and Figures 2, 3, 4, and II. Its similarity to clay No. I I makes a discussion of it in detail unnecessary. 
No. i6. Paper Makers Chemical Co.'s "Fayles" Bali Clay, CORFE CASTle, DORSET, England.-This clay of clean light gray appearance was of excellent plasticity and working properties. The residue retained by the ro-mesh sieve was 0.8 per cent. The modulus of rupture of the bars made of equal parts of clay and flint was 347 pounds per square inch. Its behavior when plastic and in slip form was about the average for the clays tested. Only a small amount of carbonaceous matter, which was removed in two hours at $750^{\circ} \mathrm{C}$., was present. In burning behavior it was practically the same as the other Dorset clays shown in Figure 8, and it was placed in class 3 of the comparative color classification.

No. i 7. Paper Makers Chemical Co.'s "Grindley" Ball Clay, Newton Abbot, Devonshire, England.-In appearance this clay resembled the other clays from the same district. It was a dark brownish-gray in color, of excellent plasticity, and contained 0.8 per cent of matter coarser than would pass a I 20-mesh sieve. Typical of the Devonshire clays, it was highly carbonaceous and of high transverse strength when dry. The modulus of rupture of the clay-flint mixture was 427 pounds per square inch. It was necessary to hold the $1 / 4$-inch trial pieces at $750^{\circ} \mathrm{C}$. for Io hours in order to completely remove the black core of carbonaceous matter. It vitrified at cone 6 and remained constant in volume from that point to cone 12 . In regard to color it was included in class 3 .

No. i8. Moore and Munger's "Great Beam" Ball Clay, ENGLAND.-This clay of unknown source was probably also a Devonshire clay. It was very plastic and contained r.6 per cent of material which would not pass through a r 20 -mesh sieve. Its modulus of rupture of 454 pounds per square inch showed its usefulness in giving strength to a body. The oxidation period required to remove the large amount of carbonaceous matter present was eight and one-half hours at $750^{\circ} \mathrm{C}$. It was vitrified at cone 2. The body containing 50 per cent of this clay burned to a good white, entitling it to inclusion in class $\mathrm{I}$.

No. I9. Cooley Ball and Sagger Clay Co.'s Kentucky Ball Clay No. 9.-Coming from the same vicinity and being almost the same in appearance as No. I4, it was to be expected that its properties would be very much like those of that clay. In color it was a clean white, looking more like a china clay than a ball clay. It slaked easily and was of good plasticity. No residue was retained by the I20-mesh sieve. Its strength was low, as 
shown by the modulus of rupture of 253 pounds per square inch. The behavior in slip form was near the average of the clays tested and its cohesion when plastic was low. Like No. I4, it was completely free from carbon, its color being white at the time the sample was crushed and after it had been fired to cone 12 . Its porosity temperature relations were almost the same as those of No. I4, but its volume shrinkage during firing was greater. It made a very good white body when used to the extent of 50 per cent and was considered of the first class with respect to color.

No. 20. Mandle Clay Mining Co.'s Tennessee Ball Clay No. 3.-This very plastic clay required the largest amount of water of plasticity- 53.3 per cent - of any of the clays tested. It differed in color from the other Tennessee clays, being a clean gray instead of the pinkish brown of the others. All but 0.3 per cent passed a I 2O-mesh sieve. Its strength was good, as shown by the modulus of rupture, 327 pounds per square inch, of the clay-flint bars. Its cohesion was above the average, and the resistance to flow of slips containing it appeared to indicate it to be of very good plasticity. The small amount of carbon in the clay disappeared after two hours of oxidizing at $750^{\circ} \mathrm{C}$. It vitrified at cone $\mathrm{I} 2$ and showed the changing volume with increase in burning temperature typical of American ball clays. Its color was fair.

No. 2I. MOORE AND MUnger's "M. \& M." English Ball, CLAY.-This clay, of indefinitely known source, apparently was from one of the Devonshore districts. It was very plastic, contained 1.4 per cent of material coarser than $\mathrm{I} 2 \mathrm{O}$ mesh, and was of very good strength. Its modulus of rupture when mixed with flint was 384 pounds per square inch. The carbonaceous core was not completely removed from the trial pieces until they had been oxidized seven and one-half hours at $750^{\circ} \mathrm{C}$. The clay vitrified at cone 4 and belonged in class 2 in regard to color.

\section{CLASSIFICATION OF BALL CLAYS.}

From the data obtained a classification of the ball clays studied has been drawn. On account of the wide variety of properties considered it was somewhat difficult to draw a strict classification which would incorporate all of the characteristics of the clays. In the following classification an attempt has been made to separate the clays into groups of the predominating types.

Class D.-This class includes sticky clays, strong in the dry state, usually black or brown, high in carbonaceous matter, and 
difficult to oxidize, usually leaving residues on the I 2O-mesh sieve and burning to a good color with the burning behavior typical of English ball clays. If used to excess, these clays have a tendency to stick to the jigger tool, causing "pulling out." This group has been subdivided according to the transverse strength of the clay in the clay-flint mixture.

(I) Transverse Strength Over 500 Pounds per Square Inch.Laboratory No. 3, English ball clay No. I 2 (Luke Knowles); Laboratory No. 7, "Superior" ball clay (Moore \& Munger).

(2) Transverse Strength 400-500 Pounds per Square Inch.Laboratory No. 13, "Dorset" ball clay (John Sant \& Sons); Laboratory No. I8, "Great Beam" ball clay (Moore \& Munger); Laboratory No. 4, "Whiteway" English ball clay (Hammill \& Gillespie); Laboratory No. 5, English ball clay No. 90 (Paper Makers Chemical Co.); Laboratory No. I 7, "Grindley" ball clay (Paper Makers Chemical Co.).

(3) Transverse Strength 375-40o Pounds per Square Inch.Laboratory No. 2, English ball clay No. 2 (Luke Knowles); Laboratory No. 22, "M. \& M." English ball clay (Moore \& Munger).

Class E.-The clays of this class are very plastic, of the lubricating type, blue or gray in color, contain little carbonaceous matter, and leave only a small residue on the r 20 -mesh sieve. They are not as strong as class D and the color is not quite as good. The burning behavior is typical of English ball clays, and they yield excellent jiggering qualities with almost perfect behavior under the tool. The transverse strength of the clay-flint mixtures is from 350 to 400 pounds per square inch. Laboratory No. I, English ball clay No. I (Luke Knowles); Laboratory No. 6, "Pikes" ball clay (Joshua Poole); Laboratory No. Io, blue ball clay No. 25 (C. M. Franzheim) ; Laboratory No. I I, "Devon" ball clay (C. M. Franzheim); Laboratory No. I 5, English ball clay No. I I (Moore \& Munger); Laboratory No. I6, "Fayles ball clay (Paper Makers Chemical Co.).

Class F.-Only one of the clays tested belongs in class F. This clay is similar to the very plastic clays of class $D$ in all respects, except that it does not have the burning behavior typical of English ball clays. The transverse strength in clay-flint mixtures is above 400 pounds per square inch, and vitrification occurs at cone 8. Laboratory No. 9, Tennessee ball clay No. 5 (Mandle Clay Mining Co.).

Class G.-The only clay in this class is a plastic clay similar to that of class F, but not vitrifying until cone ro. Its transverse 
strength is between 300 and 400 pounds per square inch. Laboratory No. 20, Tennessee ball clay No. 3 (Mandle Clay Mining Co.).

CLASS H.-These clays are plastic, usually gray or pink, contain little carbonaceous matter, and leave almost no residue on the I $2 \mathrm{O}-$ mesh sieve. The transverse strength of clay-flint mixture varies from 280 to 400 pounds per square inch, and they burn to good white color and vitrify at cone $\mathbf{2}$. Laboratory No. 8, Kentucky ball clay No. 4 (Kentucky Construction \& Improvement Co.); Laboratory No. I2, Tennessee ball clay No. I I (Johnson-Porter Clay Co.).

CLASS J.-The clays of class J are white, free from carbonaceous matter, and leave no residue on the $120-$ mesh sieve. The transverse strength when mixed with flint lies between 200 and 280 pounds per square inch. They burn to fair white, but are not vitrified at cone I2. Laboratory No. I3, Kentucky ball clay No. 9 (Cooley Ball \& Sagger Clay Co.); Laboratory No. 14, Kentucky ball clay No. Io (Cooley Ball \& Sagger Clay Co.).

\section{CONCLUSIONS.}

From the results of the tests made on these 2I ball clays now in use in the manufacture of white ceramic products the following conclusions are summarized:

I. In regard to water of plasticity and volume drying shrinkage the clays tested are very much alike with the exception of the Dorset clays, which are higher in drying shrinkage.

2. The English clays, in general, are of greater bonding power than the American clays. The Devonshire clays as a class are the stronger, the Dorset clays being next in strength. Of the domestic clays those from Tennessee are of good bonding power. One of the Kentucky clays is of good strength, but the others are low in this respect.

3. The American clays contain less coarse mineral and organic matter than the imported clays and the Kentucky clays less than the Tennessee clays.

4. The behavior of slips of clay in the simple efflux viscosimeter does not appear to be a reliable criterion of plastic qualities of clays.

5. No distinctions based on the usefulness of the clays could be drawn from the determination of the cohesiveness of the clays. While this factor differentiates between ball clays and kaolins the results are not of value in differentiating between ball clays. 
6. Some of the English ball clays are very high in carbonaceous matter and are apt to cause trouble when no allowance for this fact is made in firing. The Devonshire clays require the longest time for oxidation. The clays from Dorset contain a moderate amount of matter requiring oxidation. Tennessee ball clay No. 5 is difficult to oxidize, but the other Tennessee clays contain only a small amount of carbon. The Kentucky clays contain very little material requiring oxidation.

7. The English clays vitrify at a low temperature, cone or to cone 6 , and remain constant in volume and porosity through a wide range in temperature. The American clays are constantly changing in porosity and volume throughout the temperature range studied. The Tennessee clays vitrify at from cone 8 to cone I2. The Kentucky clays are just approaching vitrification at cone I2. None of the ball clays studied showed signs of overfiring at cone I2. Ball clays from the same district show little difference in burning behavior.

8. In general, the American clays are equal to or better than most of the imported clays in regard to the color produced in the body by their use.

9. Although in some ways the English clays are superior to the American clays for use in ceramic bodies, there are other offsetting factors in favor of the latter which tend to favor the exclusive use of domestic clays in case the deposits of English clays should become scarce or inaccessible.

10. The American clays are nearly equal to the English in plastic working qualities, but give less strength to the body when dry. However, since they are cleaner and burn, in general, to a better color than most of the English clays, they may be used in larger amounts without affecting the color of the product, thereby in a measure overcoming their lower strength. The American clays are less apt to cause trouble from lack of oxidation of the carbonaceous matter. By firing to a little higher temperature or adjusting the flux content of the body the same degree of vitrification may be obtained in a body containing domestic ball clay as in the same body when an imported clay is used. Owing to the variation in porosity and volume of the American clays with slight changes in heat treatment, somewhat more exact firing would be required to produce ware of the same uniformity of porosity and size than with the English clays.

II. The difference in burning behavior is the main reason why attempts to wholly substitute the American clays for the English 
have not been entirely successful. The substitution of an American clay for an imported one makes a more porous body under the same firing conditions, which in some types of ware may lead to crazing. Successful substitution requires either a little higher firing temperature or adjustment of the flux content of the body to produce the same degree of vitrification. The lack of constancy in porosity and volume is more difficult to overcome, but by the development of more exact firing treatment by the expert use of the more advanced types of periodic kilns and the continuous kiln this variation could be minimized.

A. V. Bleininger made suggestions in outlining the work and gave advice in preparing the report.

TABLE 1.-Miscellaneous Properties of Ball Clays.

\begin{tabular}{|c|c|c|c|c|c|c|c|c|c|}
\hline $\begin{array}{l}\text { Labora- } \\
\text { tory No. }\end{array}$ & Name of clay. & $\begin{array}{c}\text { Water } \\
\text { of plas- } \\
\text { ticity. }\end{array}$ & $\begin{array}{l}\text { Volume } \\
\text { drying } \\
\text { shrink- } \\
\text { age. }\end{array}$ & Shrink- $\begin{array}{c}\text { Sge } \\
\text { water. }\end{array}$ & $\begin{array}{c}\text { Pore } \\
\text { water. }\end{array}$ & $\begin{array}{c}\text { Ratio } \\
\text { pore } \\
\text { water } \\
\text { to } \\
\text { shrink- } \\
\text { age } \\
\text { water. }\end{array}$ & $\begin{array}{l}\text { Den- } \\
\text { sity } \\
\text { dried } \\
\text { clay. }\end{array}$ & $\begin{array}{c}\text { Resi- } \\
\text { due on } \\
120 \\
\text { mesh. }\end{array}$ & $\begin{array}{l}\text { Modu- } \\
\text { lus of } \\
\text { rup- } \\
\text { ture } \\
1 \text { clay- } \\
1 \text { flint. }\end{array}$ \\
\hline & $\begin{array}{l}\text { English ball clay No. } 1 \ldots . \\
\text { English ball clay No. } 2 \ldots \\
\text { English ball clay No. } 12 . . \\
\text { "Whiteway" ball clay.... } \\
\text { English ball clay No. } 90 . .\end{array}$ & $\begin{array}{l}45.6 \\
51.9 \\
44.9 \\
39.9 \\
47.3\end{array}$ & $\begin{array}{l}28.4 \\
26.1 \\
27.7 \\
28.4 \\
29.6\end{array}$ & $\begin{array}{l}24.3 \\
24.7 \\
23.9 \\
22.3 \\
26.3\end{array}$ & $\begin{array}{l}21.3 \\
27.2 \\
21.0 \\
17.5 \\
21.0\end{array}$ & $\begin{array}{r}0.88 \\
1.10 \\
.88 \\
.78 \\
.80\end{array}$ & $\begin{array}{l}1.667 \\
1.413 \\
1.627 \\
1.738 \\
1.627\end{array}$ & $\begin{array}{r}0.2 \\
1.5 \\
.7 \\
.4 \\
.7\end{array}$ & $\begin{array}{l}376 \\
375 \\
568 \\
446 \\
441\end{array}$ \\
\hline $\begin{array}{r}6 \ldots \ldots . \\
7 \ldots \ldots . \\
8 \ldots \ldots \\
9 \ldots \ldots . \\
10 \ldots \ldots .\end{array}$ & 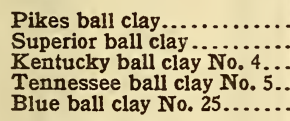 & $\begin{array}{l}46.3 \\
46.4 \\
46.7 \\
51.9 \\
48.3\end{array}$ & $\begin{array}{l}32.2 \\
28.2 \\
28.1 \\
29.2 \\
33.5\end{array}$ & $\begin{array}{l}27.9 \\
24.6 \\
24.7 \\
26.5 \\
29.5\end{array}$ & $\begin{array}{l}18.4 \\
21.8 \\
21.8 \\
25.4 \\
18.8\end{array}$ & $\begin{array}{l}.66 \\
.89 \\
.88 \\
.96 \\
.64\end{array}$ & $\begin{array}{l}1.742 \\
1.598 \\
1.593 \\
1.537 \\
1.712\end{array}$ & $\begin{array}{r}.2 \\
1.2 \\
.1 \\
.4 \\
.9\end{array}$ & $\begin{array}{l}381 \\
563 \\
372 \\
478 \\
403\end{array}$ \\
\hline ........ & $\begin{array}{l}\text { Devon ball clay ............. } \\
\text { Tennessee ball ciay No. ii. } \\
\text { Dorset ball clay .... } \ldots \ldots . . . \\
\text { Kentucky ball clay No. } 10 . . \\
\text { English ball clay No. } 11 \ldots .\end{array}$ & $\begin{array}{l}43.3 \\
44.5 \\
45.9 \\
38.3 \\
48.5\end{array}$ & $\begin{array}{l}26.5 \\
26.0 \\
33.0 \\
25.5 \\
33.5\end{array}$ & $\begin{array}{l}21.9 \\
21.9 \\
28.1 \\
19.7 \\
29.2\end{array}$ & $\begin{array}{l}21.4 \\
22.5 \\
17.8 \\
18.6 \\
19.3\end{array}$ & $\begin{array}{r}.98 \\
1.02 \\
.64 \\
.94 \\
.66\end{array}$ & & $\begin{array}{l}.4 \\
.1 \\
.1 \\
.0 \\
.3\end{array}$ & $\begin{array}{l}345 \\
293 \\
492 \\
223 \\
396\end{array}$ \\
\hline $\begin{array}{l}16 \ldots \ldots \\
17 \ldots \ldots \\
18 \ldots \ldots \\
19 \ldots \ldots \\
20 \ldots \ldots \\
22 \ldots \ldots\end{array}$ & 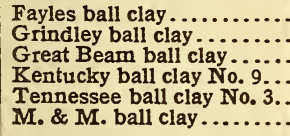 & $\begin{array}{l}47.0 \\
45.8 \\
47.6 \\
41.5 \\
53.3 \\
45.8\end{array}$ & $\begin{array}{l}32.7 \\
29.1 \\
28.8 \\
27.0 \\
27.6 \\
28.1\end{array}$ & $\begin{array}{l}28.3 \\
25.3 \\
25.6 \\
22.1 \\
29.9 \\
24.7\end{array}$ & $\begin{array}{l}18.7 \\
20.5 \\
22.0 \\
19.4 \\
23.4 \\
21.1\end{array}$ & $\begin{array}{l}.66 \\
.81 \\
.86 \\
.88 \\
.78 \\
.86\end{array}$ & $\begin{array}{l}1.714 \\
1.623 \\
1.577 \\
1.671 \\
1.545 \\
1.587\end{array}$ & $\begin{array}{r}.8 \\
.8 \\
1.6 \\
.0 \\
.3 \\
1.4\end{array}$ & $\begin{array}{l}347 \\
427 \\
454 \\
253 \\
327 \\
384\end{array}$ \\
\hline
\end{tabular}


TABLE 2.-Relative Resistance to Flow of Clay Slips.

[Water equals 1.000.]

\begin{tabular}{|c|c|c|c|c|c|c|c|c|}
\hline $\begin{array}{c}\text { Laboratory } \\
\text { No. }\end{array}$ & $\begin{array}{l}\text { Percent- } \\
\text { age clay } \\
\text { in slip. }\end{array}$ & $\begin{array}{l}\text { Relative } \\
\text { resist- } \\
\text { ance to } \\
\text { flow. }\end{array}$ & $\begin{array}{c}\text { Laboratory } \\
\text { No. }\end{array}$ & $\begin{array}{l}\text { Percent- } \\
\text { age clay } \\
\text { in slip. }\end{array}$ & $\begin{array}{l}\text { Relative } \\
\text { resist- } \\
\text { ance to } \\
\text { flow. }\end{array}$ & $\begin{array}{c}\text { Laboratory } \\
\text { No. }\end{array}$ & $\begin{array}{l}\text { Percent- } \\
\text { age clay } \\
\text { in slip. }\end{array}$ & $\begin{array}{l}\text { Relative } \\
\text { resist- } \\
\text { ance to } \\
\text { flow. }\end{array}$ \\
\hline 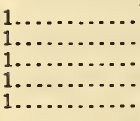 & $\begin{array}{r}5.08 \\
14.54 \\
24.72 \\
29.07 \\
35.14\end{array}$ & $\begin{array}{l}1.015 \\
1.065 \\
1.570 \\
2.330 \\
(1)\end{array}$ & $\begin{array}{l}8 \ldots \ldots \ldots \\
8 \ldots \ldots \ldots \\
8 \ldots \ldots \ldots \\
8 \ldots \ldots \ldots \\
8 \ldots \ldots \ldots \ldots\end{array}$ & $\begin{array}{r}5.35 \\
14.36 \\
24.18 \\
33.06 \\
37.42\end{array}$ & $\begin{array}{l}1.022 \\
1.070 \\
1.210 \\
2.200 \\
(1)\end{array}$ & $\begin{array}{l}15 \ldots \ldots \\
15 \ldots \ldots \\
15 \ldots \ldots \\
15 \ldots \ldots\end{array}$ & $\begin{array}{r}5.00 \\
13.61 \\
22.30 \\
30.60 \\
38.37\end{array}$ & $\begin{array}{l}1.026 \\
1.046 \\
1.220 \\
2.137 \\
(1)\end{array}$ \\
\hline $\begin{array}{l}2 \ldots \ldots \ldots \\
2 \ldots \ldots \ldots \\
2 \ldots \ldots \ldots \\
2 \ldots \ldots \ldots \\
2 \ldots \ldots \ldots\end{array}$ & $\begin{array}{r}4.96 \\
11.47 \\
21.32 \\
27.32 \\
30.70\end{array}$ & $\begin{array}{l}1.014 \\
1.027 \\
1.090 \\
1.238 \\
2.065\end{array}$ & $\begin{array}{l}9 \ldots \ldots \ldots \\
9 \ldots \ldots \ldots \ldots \\
9 \ldots \ldots \ldots \ldots \\
9 \ldots \ldots \ldots \ldots \\
9 \ldots \ldots \ldots \ldots\end{array}$ & $\begin{array}{r}4.52 \\
12.60 \\
20.05 \\
27.63 \\
34.40\end{array}$ & $\begin{array}{l}1.005 \\
1.035 \\
1.057 \\
1.102 \\
1.295\end{array}$ & $\begin{array}{l}16 \ldots \ldots \ldots \\
16 \ldots \ldots \\
16 \ldots \ldots \\
16 \ldots \ldots \\
16 \ldots \ldots\end{array}$ & $\begin{array}{r}6.05 \\
13.83 \\
23.65 \\
32.60 \\
39.28\end{array}$ & $\begin{array}{l}1.016 \\
1.076 \\
1.264 \\
1.920 \\
(1)\end{array}$ \\
\hline $\begin{array}{l}3 \ldots \ldots \ldots \\
3 \ldots \ldots \ldots \\
3 \ldots \ldots \ldots \\
3 \ldots \ldots \ldots \\
3 \ldots \ldots \ldots \ldots\end{array}$ & $\begin{array}{r}4.62 \\
13.08 \\
21.10 \\
29.50 \\
39.03\end{array}$ & $\begin{array}{l}1.008 \\
1.018 \\
1.032 \\
1.088 \\
3.330\end{array}$ & $\begin{array}{l}10 \ldots \ldots \ldots \\
10 \ldots \ldots \\
10 \ldots \ldots \\
10 \ldots \ldots \\
10 \ldots \ldots\end{array}$ & $\begin{array}{r}5.04 \\
14.04 \\
22.78 \\
31.68 \\
39.18\end{array}$ & $\begin{array}{l}1.026 \\
1.073 \\
1.434 \\
2.765 \\
(1)\end{array}$ & $\begin{array}{l}17 \ldots \ldots \ldots \\
17 \ldots \ldots \\
17 \ldots \ldots \\
17 \ldots \ldots \\
17 \ldots \ldots\end{array}$ & $\begin{array}{r}4.97 \\
13.08 \\
21.33 \\
30.48 \\
35.02\end{array}$ & $\begin{array}{l}1.009 \\
1.014 \\
1.032 \\
1.172 \\
1.744\end{array}$ \\
\hline $\begin{array}{l}4 \ldots \ldots \\
4 \ldots \ldots \ldots \\
4 \ldots \ldots \ldots \\
4 \ldots \ldots \ldots\end{array}$ & $\begin{array}{r}4.88 \\
13.77 \\
22.71 \\
32.00 \\
39.12\end{array}$ & $\begin{array}{l}1.018 \\
1.037 \\
1.086 \\
1.345 \\
4.180\end{array}$ & $\begin{array}{l}11 \ldots \ldots \ldots \\
11 \ldots \ldots \ldots \\
11 \ldots \ldots \\
11 \ldots \ldots \\
11 \ldots \ldots\end{array}$ & $\begin{array}{r}5.17 \\
13.48 \\
21.67 \\
29.75 \\
32.46\end{array}$ & $\begin{array}{l}1.012 \\
1.110 \\
1.397 \\
3.050 \\
6.060\end{array}$ & $\begin{array}{l}18 \ldots \ldots \\
18 \ldots \ldots \\
18 \ldots \ldots \\
18 \ldots \ldots \\
18 \ldots \ldots\end{array}$ & $\begin{array}{r}4.73 \\
12.38 \\
20.60 \\
28.33 \\
33.90\end{array}$ & $\begin{array}{l}1.014 \\
1.028 \\
1.083 \\
1.437 \\
3.730\end{array}$ \\
\hline $\begin{array}{l}5 \ldots \ldots \ldots \\
5 \ldots \ldots \ldots \\
5 \ldots \ldots \ldots \\
5 \ldots \ldots \\
5 \ldots \ldots \ldots\end{array}$ & $\begin{array}{r}5.20 \\
13.06 \\
22.45 \\
30.86 \\
37.90\end{array}$ & $\begin{array}{l}1.028 \\
1.042 \\
1.068 \\
1.350 \\
3.120\end{array}$ & $\begin{array}{l}12 \ldots \ldots \ldots \\
12 . \ldots \ldots \\
12 \ldots \ldots \\
12 \ldots \ldots \\
12 \ldots \ldots\end{array}$ & $\begin{array}{r}4.83 \\
12.53 \\
20.30 \\
27.72 \\
34.14\end{array}$ & $\begin{array}{l}1.017 \\
1.060 \\
1.350 \\
6.060 \\
(1)\end{array}$ & $\begin{array}{l}19 \ldots \ldots \ldots \\
19 \ldots \ldots \ldots \\
19 \ldots \ldots \\
19 \ldots \ldots \\
19 \ldots \ldots\end{array}$ & $\begin{array}{r}4.96 \\
14.23 \\
24.13 \\
29.04 \\
36.14\end{array}$ & $\begin{array}{l}1.028 \\
1.123 \\
1.770 \\
2.370 \\
(1)\end{array}$ \\
\hline $\begin{array}{l}6 \ldots \ldots \ldots \\
6 \ldots \ldots \ldots \\
6 \ldots \ldots \ldots \\
6 \ldots \ldots \\
6 \ldots \ldots \ldots \\
6 . \ldots \ldots \\
\end{array}$ & $\begin{array}{r}5.46 \\
13.76 \\
22.80 \\
30.81 \\
37.04\end{array}$ & $\begin{array}{l}1.032 \\
1.120 \\
1.368 \\
2.820 \\
\text { (1) }\end{array}$ & $\begin{array}{l}13 \ldots \ldots \ldots \\
13 \ldots \ldots \\
13 \ldots \ldots \\
13 \ldots \ldots \\
13 \ldots \ldots\end{array}$ & $\begin{array}{r}5.58 \\
13.84 \\
23.20 \\
31.90 \\
39.05\end{array}$ & $\begin{array}{l}1.027 \\
1.072 \\
1.455 \\
2.300 \\
(1)\end{array}$ & $\begin{array}{l}20 \ldots \ldots \ldots \\
20 \ldots \ldots \ldots \\
20 \ldots \ldots \\
20 \ldots \ldots \\
20 \ldots \ldots\end{array}$ & $\begin{array}{r}5.12 \\
13.98 \\
22.60 \\
31.80 \\
39.46\end{array}$ & $\begin{array}{r}1.014 \\
1.066 \\
1.416 \\
2.660 \\
(1)\end{array}$ \\
\hline $\begin{array}{l}7 \ldots \ldots \\
7 \ldots \ldots \\
7 \ldots \ldots \\
7\end{array}$ & $\begin{array}{r}5.13 \\
13.20 \\
21.91 \\
30.00 \\
36.65\end{array}$ & $\begin{array}{l}1.018 \\
1.047 \\
1.158 \\
1.483 \\
2.246\end{array}$ & $\begin{array}{l}14 \ldots \ldots \\
14 \ldots \ldots \\
14 \ldots \ldots \\
14 \ldots \ldots \\
14 \ldots \ldots\end{array}$ & $\begin{array}{r}5.28 \\
13.37 \\
21.14 \\
31.53 \\
39.08\end{array}$ & $\begin{array}{l}1.027 \\
1.088 \\
1.320 \\
2.256 \\
\text { (I) }\end{array}$ & $\begin{array}{l}22 \ldots \ldots \ldots \ldots \\
22 \ldots \ldots \ldots \\
22 \ldots \ldots \ldots \\
22 \ldots \ldots \ldots \\
22 \ldots \ldots \ldots\end{array}$ & $\begin{array}{r}5.27 \\
13.95 \\
21.20 \\
32.96 \\
37.14\end{array}$ & $\begin{array}{l}1.008 \\
1.047 \\
1.096 \\
3.010 \\
(1)\end{array}$ \\
\hline
\end{tabular}

\footnotetext{
1 The slip would not flow out of the apparatus.
} 
TABLE 3.-Cohesion of the Clays in Plastic Condition.

[Cohesion in grams per square centimeter.]

\begin{tabular}{|c|c|c|c|c|c|c|c|c|}
\hline $\begin{array}{c}\text { Laboratory } \\
\text { No. }\end{array}$ & $\begin{array}{l}\text { Per- } \\
\text { centage } \\
\text { water. }\end{array}$ & $\begin{array}{l}\text { Cohe- } \\
\text { sion. }\end{array}$ & $\begin{array}{c}\text { Laboratory } \\
\text { No. }\end{array}$ & $\begin{array}{l}\text { Per- } \\
\text { centage } \\
\text { water. }\end{array}$ & $\begin{array}{l}\text { Cohe- } \\
\text { sion. }\end{array}$ & $\begin{array}{c}\text { Laboratory } \\
\text { No. }\end{array}$ & $\begin{array}{l}\text { Per- } \\
\text { centage } \\
\text { water. }\end{array}$ & $\begin{array}{l}\text { Cohe- } \\
\text { sion. }\end{array}$ \\
\hline 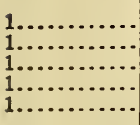 & $\begin{array}{l}32.5 \\
35.0 \\
37.5 \\
40.0 \\
42.5\end{array}$ & $\begin{array}{r}105.5 \\
97.2 \\
95.9 \\
76.2 \\
71.6\end{array}$ & $\begin{array}{l}8 \ldots \ldots \ldots \\
8 \ldots \ldots \ldots \\
8 \ldots \ldots \ldots \ldots \\
8 \ldots \ldots \ldots \ldots \\
8 \ldots \ldots \ldots \ldots\end{array}$ & $\begin{array}{l}35.0 \\
37.5 \\
40.0 \\
42.5 \\
45.0\end{array}$ & $\begin{array}{r}143.5 \\
124.8 \\
95.4 \\
\ldots . . . \\
72.6\end{array}$ & $\begin{array}{l}15 \ldots \ldots \ldots \\
15 \ldots \ldots \ldots \\
15 \ldots \ldots \ldots \\
15 \ldots \ldots \ldots \\
15 \ldots \ldots\end{array}$ & $\begin{array}{l}32.5 \\
35.0 \\
37.5 \\
40.0 \\
42.5\end{array}$ & $\begin{array}{r}139.5 \\
114.9 \\
103.2 \\
84.4 \\
51.7\end{array}$ \\
\hline 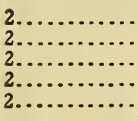 & $\begin{array}{l}35.0 \\
37.5 \\
40.0 \\
42.5 \\
45.0\end{array}$ & $\begin{array}{r}153.2 \\
110.5 \\
97.0 \\
83.7 \\
66.0\end{array}$ & $\begin{array}{l}9 \ldots \ldots \ldots \\
9 \ldots \ldots \ldots \\
9 \ldots \ldots \ldots \\
9 \ldots \ldots \ldots \\
9 \ldots \ldots \ldots \ldots\end{array}$ & $\begin{array}{l}35.0 \\
37.5 \\
40.0 \\
42.5 \\
45.0\end{array}$ & $\begin{array}{r}146.4 \\
109.0 \\
93.0 \\
76.5 \\
64.7\end{array}$ & $\begin{array}{l}16 \ldots \ldots \ldots \\
16 \ldots \ldots \\
16 \ldots \ldots \\
16 \ldots \ldots \\
16 \ldots \ldots\end{array}$ & $\begin{array}{l}32.5 \\
35.0 \\
37.5 \\
40.0 \\
42.5\end{array}$ & $\begin{array}{r}131.9 \\
106.2 \\
103.0 \\
90.6 \\
76.0\end{array}$ \\
\hline 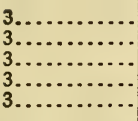 & $\begin{array}{l}32.5 \\
35.0 \\
37.5 \\
40.0 \\
42.5\end{array}$ & $\begin{array}{r}149.0 \\
121.5 \\
116.4 \\
85.0 \\
71.2\end{array}$ & $\begin{array}{l}10 \ldots \ldots \ldots \\
10 \ldots \ldots \ldots \\
10 \ldots \ldots \\
10 \ldots \ldots \ldots \\
10 \ldots \ldots\end{array}$ & $\begin{array}{l}35.0 \\
37.5 \\
40.0 \\
42.5 \\
45.0\end{array}$ & $\begin{array}{r}140.0 \\
101.2 \\
84.9 \\
70.2 \\
61.5\end{array}$ & $\begin{array}{l}17 \ldots \ldots \ldots \\
17 \ldots \ldots \ldots \\
17 \ldots \ldots \ldots \\
17 \ldots \ldots \ldots \\
17 \ldots \ldots \ldots \ldots\end{array}$ & $\begin{array}{l}35.0 \\
37.5 \\
40.0 \\
42.5 \\
45.0\end{array}$ & $\begin{array}{r}121.8 \\
76.5 \\
71.2 \\
64.5 \\
59.5\end{array}$ \\
\hline ……..... & $\begin{array}{l}30.0 \\
32.5 \\
35.0 \\
37.5 \\
40.0\end{array}$ & \begin{tabular}{r|}
143.1 \\
123.2 \\
114.8 \\
83.4 \\
61.4
\end{tabular} & $\begin{array}{l}11 \ldots \ldots \ldots \\
11 \ldots \ldots \ldots \\
11 \ldots \ldots \ldots \\
11 \ldots \ldots \\
11 \ldots \ldots\end{array}$ & $\begin{array}{l}40.0 \\
42.5 \\
45.0 \\
47.5 \\
50.0\end{array}$ & $\begin{array}{r}131.0 \\
106.8 \\
94.4 \\
78.4 \\
54.8\end{array}$ & $\begin{array}{l}18 \ldots \ldots \ldots \\
18 \ldots \ldots \ldots \\
18 \ldots \ldots \ldots \\
18 \ldots \ldots \ldots \\
18 \ldots \ldots \ldots\end{array}$ & $\begin{array}{l}37.5 \\
40.0 \\
42.5 \\
45.0 \\
47.5\end{array}$ & $\begin{array}{r}119.0 \\
93.5 \\
82.0 \\
72.7 \\
60.5\end{array}$ \\
\hline & $\begin{array}{l}35.0 \\
37.5 \\
40.0 \\
42.5 \\
45.0\end{array}$ & $\begin{array}{r}133.5 \\
105.8 \\
74.1 \\
64.0 \\
54.9\end{array}$ & $\begin{array}{l}12 \ldots \ldots \ldots \ldots \\
12 \ldots \ldots \ldots \ldots \\
12 \ldots \ldots \ldots \\
12 \ldots \ldots \ldots \\
12 \ldots \ldots \ldots\end{array}$ & $\begin{array}{l}35.0 \\
37.5 \\
40.0 \\
42.5 \\
45.0\end{array}$ & $\begin{array}{r}137.2 \\
117.1 \\
104.0 \\
58.6 \\
43.6\end{array}$ & $\begin{array}{l}19 \ldots \ldots \ldots \\
19 \ldots \ldots \ldots \\
19 \ldots \ldots \ldots \\
19 \ldots \ldots \ldots \\
19 \ldots \ldots \ldots \ldots\end{array}$ & $\begin{array}{l}32.5 \\
35.0 \\
37.5 \\
40.0 \\
42.5\end{array}$ & $\begin{array}{r}120.0 \\
81.5 \\
75.5 \\
72.0 \\
62.3\end{array}$ \\
\hline .............. & $\begin{array}{l}40.0 \\
42.5 \\
45.0 \\
47.5 \\
50.0\end{array}$ & $\begin{array}{r}144.3 \\
114.5 \\
95.3 \\
75.1 \\
55.7\end{array}$ & $\begin{array}{l}13 \ldots \ldots \ldots \\
13 \ldots \ldots \\
13 \ldots \ldots \ldots \\
13 \ldots \ldots \ldots \\
13 \ldots \ldots \ldots\end{array}$ & $\begin{array}{l}32.5 \\
35.0 \\
37.5 \\
40.0 \\
42.5\end{array}$ & $\begin{array}{r}153.8 \\
126.7 \\
109.4 \\
83.9 \\
63.7\end{array}$ & $\begin{array}{l}20 \ldots \ldots \ldots \\
20 \ldots \ldots \ldots \\
20 \ldots \ldots \ldots \ldots \\
20 \ldots \ldots \ldots \\
20 \ldots \ldots \ldots \ldots\end{array}$ & $\begin{array}{l}37.5 \\
40.0 \\
42.5 \\
45.0 \\
47.5\end{array}$ & $\begin{array}{r}127.0 \\
109.2 \\
65.6 \\
64.4 \\
59.2\end{array}$ \\
\hline 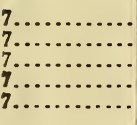 & $\begin{array}{l}32.5 \\
35.0 \\
37.5 \\
40.0 \\
42.5\end{array}$ & $\begin{array}{r}148.0 \\
123.5 \\
113.4 \\
86.4 \\
59.2\end{array}$ & $\begin{array}{l}14 \ldots \ldots \ldots \\
14 \ldots \ldots \ldots \\
14 \ldots \ldots \ldots \\
14 \ldots \ldots \ldots \\
14 \ldots \ldots \ldots\end{array}$ & $\begin{array}{l}30.0 \\
32.5 \\
35.0 \\
37.5 \\
40.0\end{array}$ & $\begin{array}{r}135.2 \\
113.4 \\
89.2 \\
60.6 \\
45.6\end{array}$ & 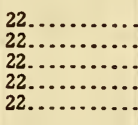 & $\begin{array}{l}37.5 \\
40.0 \\
42.5 \\
45.0 \\
47.5\end{array}$ & $\begin{array}{r}137.0 \\
125.0 \\
114.2 \\
100.8 \\
72.2\end{array}$ \\
\hline
\end{tabular}

TABLE 4.-Time Required for Oxidation at $750^{\circ} \mathrm{C}$.

\begin{tabular}{r|r|r|r}
\hline Labora- \\
tory No.
\end{tabular}


TABLE 5.-Percentage Apparent Porosity.

\begin{tabular}{|c|c|c|c|c|c|c|c|c|}
\hline $\begin{array}{l}\text { Labora- } \\
\text { tory No. }\end{array}$ & Clay. & $\begin{array}{c}\text { Cone } \\
01 \text {. }\end{array}$ & $\begin{array}{c}\text { Cone } \\
2 .\end{array}$ & $\begin{array}{c}\text { Cone } \\
4 .\end{array}$ & $\begin{array}{c}\text { Cone } \\
6 .\end{array}$ & $\begin{array}{c}\text { Cone } \\
8 .\end{array}$ & $\begin{array}{c}\text { Cone } \\
10 .\end{array}$ & $\begin{array}{c}\text { Cone } \\
12 .\end{array}$ \\
\hline $\begin{array}{l}1 \ldots \ldots \ldots \\
2 \ldots \ldots \cdots \\
3 \ldots \ldots \ldots \\
4 \ldots \ldots \ldots \\
5 \ldots \ldots\end{array}$ & 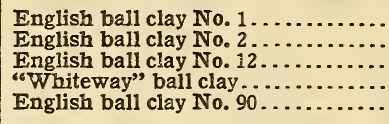 & $\begin{array}{r}14.3 \\
26.2 \\
12.3 \\
14.2 \\
7.7\end{array}$ & $\begin{array}{r}5.0 \\
15.4 \\
1.4 \\
11.6 \\
4.9\end{array}$ & $\begin{array}{l}0.3 \\
7.7 \\
1.5 \\
2.5 \\
1.2\end{array}$ & $\begin{array}{l}0.2 \\
3.9 \\
1.3 \\
.3 \\
1.2\end{array}$ & $\begin{array}{r}0.2 \\
3.9 \\
1.7 \\
.3 \\
1.0\end{array}$ & $\begin{array}{r}0.2 \\
3.6 \\
.4 \\
.3 \\
1.8\end{array}$ & $\begin{array}{r}0.4 \\
3.4 \\
.8 \\
.3 \\
1.3\end{array}$ \\
\hline $\begin{array}{r}6 \ldots \ldots \ldots \\
7 \ldots \ldots \cdots \\
8 \ldots \ldots \cdots \\
9 \ldots \ldots \\
10 \ldots \ldots\end{array}$ & 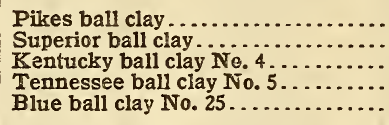 & $\begin{array}{r}12.2 \\
18.3 \\
32.1 \\
32.4 \\
3.0\end{array}$ & $\begin{array}{r}1.8 \\
13.4 \\
25.4 \\
17.8 \\
1.5\end{array}$ & $\begin{array}{r}1.5 \\
6.5 \\
18.7 \\
13.7 \\
1.3\end{array}$ & $\begin{array}{r}1.7 \\
2.9 \\
16.4 \\
10.3 \\
1.4\end{array}$ & $\begin{array}{r}2.0 \\
2.7 \\
12.4 \\
2.3 \\
.8\end{array}$ & $\begin{array}{r}1.4 \\
3.2 \\
5.5 \\
1.1 \\
.5\end{array}$ & $\begin{array}{r}1.5 \\
3.1 \\
1.4 \\
1.4 \\
.5\end{array}$ \\
\hline $\begin{array}{l}11 \ldots \ldots \cdots \\
12 \ldots \ldots \cdots \\
13 \ldots \cdots \cdots \\
14 \ldots \ldots \\
15 \ldots \ldots\end{array}$ & $\begin{array}{l}\text { Devon ball clay } \ldots \ldots \ldots \ldots \\
\text { Tennessee ball clay } \mathrm{No} .11 \ldots \ldots \\
\text { Dorset ball clay } \ldots \ldots \\
\text { Kentucky ball clay No. } 10 \ldots \ldots \\
\text { English ball clay No. } 11 \ldots \ldots\end{array}$ & $\begin{array}{r}12.5 \\
35.0 \\
5.0 \\
25.5 \\
3.2\end{array}$ & $\begin{array}{r}2.0 \\
21.9 \\
2.0 \\
22.9 \\
1.5\end{array}$ & $\begin{array}{r}.7 \\
16.0 \\
1.8 \\
22.2 \\
.7\end{array}$ & $\begin{array}{r}.7 \\
12.1 \\
2.2 \\
20.0 \\
1.4\end{array}$ & $\begin{array}{r}1.1 \\
8.5 \\
1.9 \\
14.3 \\
1.3\end{array}$ & $\begin{array}{r}1.1 \\
5.3 \\
2.0 \\
11.7 \\
1.0\end{array}$ & $\begin{array}{l}1.2 \\
3.0 \\
2.5 \\
6.8 \\
.6\end{array}$ \\
\hline $\begin{array}{l}16 \ldots \ldots \\
17 \ldots \ldots \\
18 \ldots \ldots \\
19 \ldots \ldots \\
20 \ldots \ldots \\
22 \ldots \ldots \\
\end{array}$ & 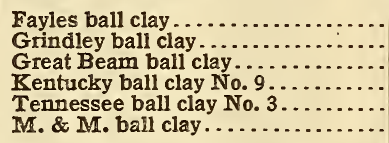 & $\begin{array}{r}1.8 \\
10.5 \\
4.2 \\
27.0 \\
24.0 \\
13.4\end{array}$ & $\begin{array}{r}1.2 \\
6.7 \\
1.0 \\
24.5 \\
21.2 \\
6.7\end{array}$ & $\begin{array}{r}.8 \\
3.5 \\
.7 \\
20.1 \\
17.6 \\
1.2\end{array}$ & $\begin{array}{r}2.0 \\
.4 \\
.7 \\
17.8 \\
15.1 \\
.8\end{array}$ & $\begin{array}{r}1.6 \\
.7 \\
1.0 \\
14.3 \\
6.4 \\
.5\end{array}$ & $\begin{array}{r}.4 \\
.5 \\
.4 \\
12.0 \\
2.5 \\
.2\end{array}$ & $\begin{array}{r}.6 \\
.8 \\
1.7 \\
7.2 \\
.7 \\
.6\end{array}$ \\
\hline
\end{tabular}

TABLE 6.-Percentage Volume Firing Shrinkage.

\begin{tabular}{|c|c|c|c|c|c|c|c|c|}
\hline $\begin{array}{l}\text { Labora- } \\
\text { lory No. }\end{array}$ & Clay. & $\begin{array}{c}\text { Cone } \\
01 .\end{array}$ & $\begin{array}{c}\text { Cone } \\
2 .\end{array}$ & $\begin{array}{c}\text { Cone } \\
4 .\end{array}$ & $\begin{array}{c}\text { Cone } \\
6 .\end{array}$ & $\begin{array}{c}\text { Cone } \\
8 .\end{array}$ & $\begin{array}{c}\text { Cone } \\
10 .\end{array}$ & $\begin{array}{c}\text { Cone } \\
12 .\end{array}$ \\
\hline $\begin{array}{l}1 \ldots \ldots \\
2 \ldots \ldots \\
3 \ldots \ldots \\
4 \ldots \ldots \\
5 \ldots \ldots \ldots\end{array}$ & 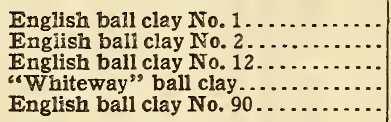 & $\begin{array}{l}30.3 \\
33.5 \\
32.3 \\
24.0 \\
34.4\end{array}$ & $\begin{array}{l}33.8 \\
40.4 \\
35.3 \\
25.8 \\
35.4\end{array}$ & $\begin{array}{l}35.7 \\
41.3 \\
35.9 \\
27.0 \\
37.1\end{array}$ & $\begin{array}{l}36.5 \\
42.9 \\
36.6 \\
29.5 \\
37.8\end{array}$ & $\begin{array}{l}37.0 \\
43.5 \\
36.9 \\
30.4 \\
37.9\end{array}$ & $\begin{array}{l}37.9 \\
44.2 \\
37.9 \\
30.4 \\
38.0\end{array}$ & $\begin{array}{l}37.2 \\
44.9 \\
37.7 \\
30.2 \\
38.2\end{array}$ \\
\hline $\begin{array}{r}6 \ldots \ldots \\
7 \ldots \ldots \ldots \\
8 \ldots \ldots \\
9 \ldots \ldots \\
10 \ldots \ldots\end{array}$ & 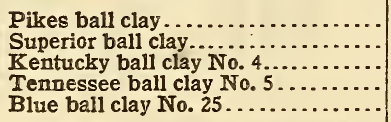 & $\begin{array}{l}28.4 \\
31.2 \\
16.9 \\
22.0 \\
33.7\end{array}$ & $\begin{array}{l}33.2 \\
35.3 \\
25.7 \\
34.1 \\
35.0\end{array}$ & $\begin{array}{l}33.9 \\
36.4 \\
31.8 \\
36.0 \\
36.0\end{array}$ & $\begin{array}{l}34.1 \\
37.9 \\
33.3 \\
38.6 \\
35.8\end{array}$ & $\begin{array}{l}34.4 \\
38.8 \\
35.2 \\
40.2 \\
36.5\end{array}$ & $\begin{array}{l}35.2 \\
39.2 \\
37.1 \\
41.7 \\
36.2\end{array}$ & $\begin{array}{l}35.3 \\
39.6 \\
39.5 \\
42.2 \\
35.7\end{array}$ \\
\hline $\begin{array}{l}11 \ldots \ldots \\
12 \ldots \ldots \ldots \\
13 \ldots \ldots \ldots \\
14 \ldots \ldots \ldots \\
15 \ldots \ldots \ldots\end{array}$ & 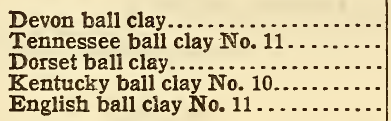 & $\begin{array}{l}35.5 \\
17.6 \\
31.8 \\
17.0 \\
33.0\end{array}$ & $\begin{array}{l}37.3 \\
31.2 \\
33.3 \\
19.6 \\
34.3\end{array}$ & $\begin{array}{l}38.6 \\
33.4 \\
33.8 \\
20.3 \\
35.1\end{array}$ & $\begin{array}{l}39.4 \\
37.5 \\
33.9 \\
22.7 \\
34.1\end{array}$ & $\begin{array}{l}39.3 \\
39.4 \\
34.5 \\
26.3 \\
33.9\end{array}$ & $\begin{array}{l}39.7 \\
41.3 \\
34.6 \\
28.0 \\
35.8\end{array}$ & $\begin{array}{l}39.7 \\
42.1 \\
34.5 \\
30.0 \\
35.4\end{array}$ \\
\hline $\begin{array}{l}16 \ldots \ldots \\
17 \ldots \ldots \ldots \\
18 \ldots \ldots \ldots \\
19 \ldots \ldots \\
20 \ldots \ldots \\
22 \ldots \ldots\end{array}$ & 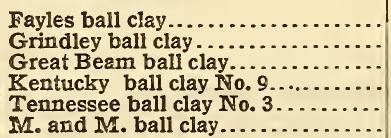 & $\begin{array}{l}33.6 \\
32.1 \\
36.9 \\
20.9 \\
29.3 \\
31.8\end{array}$ & $\begin{array}{l}34.3 \\
31.4 \\
37.8 \\
23.5 \\
31.8 \\
32.9\end{array}$ & $\begin{array}{l}34.4 \\
33.4 \\
38.7 \\
27.8 \\
35.2 \\
35.0\end{array}$ & $\begin{array}{l}34.4 \\
34.4 \\
39.1 \\
29.8 \\
36.9 \\
35.5\end{array}$ & $\begin{array}{l}35.2 \\
36.6 \\
39.9 \\
31.4 \\
39.6 \\
37.3\end{array}$ & $\begin{array}{l}36.3 \\
36.0 \\
40.2 \\
32.8 \\
40.7 \\
37.4\end{array}$ & $\begin{array}{l}35.8 \\
36.4 \\
39.9 \\
35.0 \\
42.8 \\
37.4\end{array}$ \\
\hline
\end{tabular}


TABLE 7.-True Specific Gravities and True Porosities.

\begin{tabular}{|c|c|c|c|c|c|c|c|}
\hline $\begin{array}{l}\text { Labora- } \\
\text { tory No. }\end{array}$ & Clay. & Cone. & $\begin{array}{l}\text { Appar- } \\
\text { ent } \\
\text { specific } \\
\text { gravity. }\end{array}$ & $\begin{array}{l}\text { True } \\
\text { specific } \\
\text { gravity. }\end{array}$ & $\begin{array}{c}\text { Open } \\
\text { pores in } \\
\text { terms } \\
\text { of true } \\
\text { clay } \\
\text { volume. }\end{array}$ & $\begin{array}{c}\text { Closed } \\
\text { pores in } \\
\text { terms } \\
\text { of true } \\
\text { clay } \\
\text { volume. }\end{array}$ & $\begin{array}{c}\text { Total } \\
\text { porosity } \\
\text { in terms } \\
\text { of true } \\
\text { clay } \\
\text { volume. }\end{array}$ \\
\hline 1. & English ball clay No. $1 \ldots$ & 8 & 2.393 & 2.565 & 0.2 & 7.2 & 7.4 \\
\hline 2. & English ball clay No. $2 \ldots$ & $\begin{array}{r}12 \\
8\end{array}$ & $\begin{array}{l}2.402 \\
2.108\end{array}$ & $\begin{array}{l}2.561 \\
2.573\end{array}$ & $\begin{array}{r}.5 \\
5.0\end{array}$ & $\begin{array}{r}6.6 \\
22.0\end{array}$ & $\begin{array}{r}7.1 \\
27.0\end{array}$ \\
\hline 3.. & English ball clay No. $12 .$. & $\begin{array}{r}12 \\
8 \\
12\end{array}$ & $\begin{array}{l}2.144 \\
2.296 \\
2.303\end{array}$ & $\begin{array}{l}2.583 \\
2.572 \\
2.559\end{array}$ & $\begin{array}{r}4.2 \\
2.0 \\
.9\end{array}$ & $\begin{array}{l}20.4 \\
12.0 \\
11.1\end{array}$ & $\begin{array}{l}24.6 \\
14.0 \\
12.0\end{array}$ \\
\hline $4 \ldots$ & "Whiteway" ball clay........ & 8 & 2.267 & 2.531 & .3 & 11.7 & 12.0 \\
\hline 5. & English ball clay No. $90 .$. & $\begin{array}{r}12 \\
8\end{array}$ & $\begin{array}{l}2.247 \\
2.324\end{array}$ & $\begin{array}{l}2.512 \\
2.571\end{array}$ & $\begin{array}{r}.3 \\
1.1\end{array}$ & $\begin{array}{l}11.7 \\
10.6\end{array}$ & $\begin{array}{l}12.0 \\
11.7\end{array}$ \\
\hline $6 .$. & Pikes ball clay....... & $\begin{array}{r}12 \\
8 \\
12\end{array}$ & $\begin{array}{l}2.344 \\
2.413 \\
2.437\end{array}$ & $\begin{array}{l}2.555 \\
2.596 \\
2.596\end{array}$ & $\begin{array}{l}1.4 \\
2.2 \\
1.7\end{array}$ & $\begin{array}{l}8.9 \\
7.5 \\
6.5\end{array}$ & $\begin{array}{r}10.2 \\
9.7 \\
8.2\end{array}$ \\
\hline 7. & Superior ball clay... & 8 & 2. 276 & 2.572 & 3.2 & 13.0 & 16. 2 \\
\hline & Kentucky ball clay No. $4 \ldots$ & $\begin{array}{r}12 \\
8\end{array}$ & $\begin{array}{l}2.316 \\
2.450\end{array}$ & $\begin{array}{l}2.581 \\
2.625\end{array}$ & $\begin{array}{r}3 . \overline{6} \\
15.1\end{array}$ & $\begin{array}{r}11.5 \\
7.2\end{array}$ & 22.3 \\
\hline 9.. & Tennessee ball clay No. $5 \ldots$ & $\begin{array}{r}12 \\
8 \\
12\end{array}$ & $\begin{array}{l}2.333 \\
2.222 \\
2.271\end{array}$ & $\begin{array}{l}2.567 \\
2.639 \\
2.614\end{array}$ & $\begin{array}{l}1.6 \\
2.8 \\
1.6\end{array}$ & $\begin{array}{l}10.0 \\
19.3 \\
15.1\end{array}$ & $\begin{array}{l}11.6 \\
22.1 \\
16.7\end{array}$ \\
\hline $10 .$. & Blue ball clay No. $25 \ldots$ & 8 & 2.462 & 2.589 & .8 & 5.2 & 6.0 \\
\hline 11. & Devon ball clay . . . . . . . . . . & $\begin{array}{r}12 \\
8\end{array}$ & $\begin{array}{l}2.436 \\
2.458\end{array}$ & $\begin{array}{l}2.580 \\
2.582\end{array}$ & $\begin{array}{r}.6 \\
1.2\end{array}$ & $\begin{array}{l}5.8 \\
4.9\end{array}$ & $\begin{array}{l}6.4 \\
6.1\end{array}$ \\
\hline $12 .$. & Tennessee ball clay No. $11 .$. & $\begin{array}{r}12 \\
8 \\
12\end{array}$ & $\begin{array}{l}2.475 \\
2.506 \\
2.480\end{array}$ & $\begin{array}{l}2.556 \\
2.651 \\
2.655\end{array}$ & $\begin{array}{l}1.2 \\
9.8 \\
3.3\end{array}$ & $\begin{array}{l}3.2 \\
5.8 \\
7.0\end{array}$ & $\begin{array}{r}4.4 \\
15.6 \\
10.6\end{array}$ \\
\hline $13 .$. & 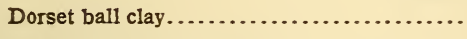 & 8 & 2.472 & 2.589 & 2.1 & 4.7 & 6.8 \\
\hline $14 .$. & Kentucky ball clay No. $10 .$. & $\begin{array}{r}12 \\
8\end{array}$ & $\begin{array}{l}2.450 \\
2.480\end{array}$ & $\begin{array}{l}2.525 \\
2.660\end{array}$ & $\begin{array}{r}2.7 \\
17.6\end{array}$ & $\begin{array}{l}3.0 \\
7.2\end{array}$ & $\begin{array}{r}5.7 \\
24.8\end{array}$ \\
\hline & English ball clay No. $11 . .$. & $\begin{array}{r}12 \\
8 \\
12\end{array}$ & $\begin{array}{l}2.410 \\
2.436 \\
2.423\end{array}$ & $\begin{array}{l}2.617 \\
2.599 \\
2.595\end{array}$ & $\begin{array}{r}7.9 \\
1.4 \\
.7\end{array}$ & $\begin{array}{l}8.6 \\
6.7 \\
7.0\end{array}$ & $\begin{array}{r}16.5 \\
8.1 \\
7.7\end{array}$ \\
\hline $16 .$. & Fayles ball clay .... & 8 & 2.421 & 2.590 & 1.7 & 6.9 & 8.6 \\
\hline & Grindley ball clay.......... & $\begin{array}{r}12 \\
8\end{array}$ & & & .8 & $\begin{array}{r}0.9 \\
14.2\end{array}$ & $\begin{array}{r}7.5 \\
15.0\end{array}$ \\
\hline 18. & Great Beam ball clay...... & $\begin{array}{r}12 \\
8 \\
12\end{array}$ & $\begin{array}{l}2.217 \\
2.297 \\
2.320\end{array}$ & $\begin{array}{l}2.523 \\
2.561 \\
2.550\end{array}$ & $\begin{array}{r}.9 \\
1.1 \\
1.9\end{array}$ & $\begin{array}{r}13.7 \\
11.4 \\
9.8\end{array}$ & $\begin{array}{l}14.6 \\
12.5 \\
11.7\end{array}$ \\
\hline & Kentucky ball clay No. $9 . .$. & 8 & 2.518 & 2.661 & 17.6 & 5.7 & 23.3 \\
\hline & Tennessee ball clay No. $3 . . . .$. & 8 & & 2.597 & 7.4 & 8.7 & 16. \\
\hline 22. & M. \& M. ball clay.. & $\begin{array}{r}12 \\
8 \\
12\end{array}$ & $\begin{array}{l}2.380 \\
2.247 \\
2.250\end{array}$ & $\begin{array}{l}2.590 \\
2.543 \\
2.525\end{array}$ & $\begin{array}{l}.8 \\
.6 \\
.6\end{array}$ & $\begin{array}{r}8.7 \\
13.2 \\
12.2\end{array}$ & $\begin{array}{r}9.5 \\
13.8 \\
12.8\end{array}$ \\
\hline
\end{tabular}


TABLE 8.-Coloring Effect of the Clays in the Standard Body.

\begin{tabular}{|c|c|c|c|}
\hline $\begin{array}{l}\text { Labora- } \\
\text { tory No. }\end{array}$ & Class. & Name of clay. & Color of body. \\
\hline 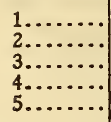 & $\begin{array}{l}2 \\
1 \\
1 \\
3 \\
2\end{array}$ & 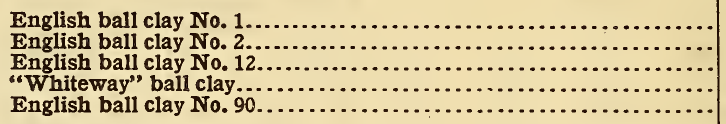 & $\begin{array}{l}\text { Very light buff. } \\
\text { White. } \\
\text { Light cream. } \\
\text { Buff. } \\
\text { Light buff. }\end{array}$ \\
\hline \begin{tabular}{r|}
$6 \ldots \ldots$ \\
$7 \ldots \ldots \ldots$ \\
$8 \ldots \ldots$ \\
$9 \ldots \ldots \ldots$ \\
$10 \ldots \ldots \ldots$
\end{tabular} & $\begin{array}{l}2 \\
2 \\
2 \\
1 \\
3\end{array}$ & 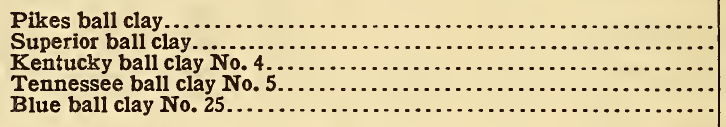 & $\begin{array}{l}\text { Cream. } \\
\text { Light buff. } \\
\text { Cream. } \\
\text { Light cream. } \\
\text { Light buff. }\end{array}$ \\
\hline 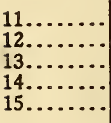 & $\begin{array}{l}2 \\
1 \\
3 \\
3 \\
3\end{array}$ & 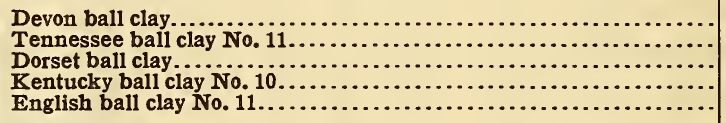 & $\begin{array}{l}\text { Do. } \\
\text { White. } \\
\text { Buff. } \\
\text { Light buff. } \\
\text { Buff. }\end{array}$ \\
\hline $\begin{array}{l}16 \ldots \ldots \\
17 \ldots \ldots \\
18 \ldots \ldots \\
19 \ldots \ldots \\
20 \ldots \ldots \\
22 \ldots \ldots\end{array}$ & $\begin{array}{l}3 \\
3 \\
1 \\
1 \\
2 \\
2\end{array}$ & 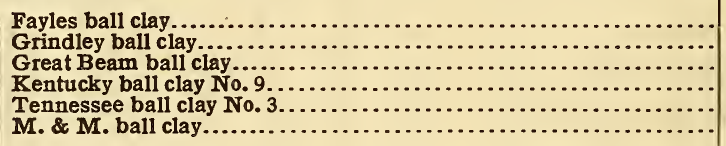 & $\begin{array}{l}\text { Do. } \\
\text { Light buff. } \\
\text { White. } \\
\text { Light cream. } \\
\text { Cream. } \\
\text { Do. }\end{array}$ \\
\hline
\end{tabular}

WASHINGTON, July I8, I922. 